• 研究报告・

\title{
欧亚大陆东部毛莨科植物多样性格局及主导因子
}

\author{
李亦超 ${ }^{1}$, 陈永生 ${ }^{1}$, Denis Sandanov ${ }^{\circledR 3}$ ，罗奥 ${ }^{1}$ ，吕童®1，苏香燕®1，刘云鹏@1，王 \\ 庆刚®2, Viktor Chepinoga ${ }^{\circledR 4}$, Sergey Dudov ${ }^{\circledR 5}$, 王伟®6, 王志恒®1*
}

1. 北京大学城市与环境学院, 北京大学生态研究中心, 北京大学地表过程分析与模拟教育部重点实验室, 北京 $100871 ; 2$. 中国农业大学资 源与环境学院, 北京市生物多样性与有机农业重点实验室, 北京 100193; 3. Institute of General and Experimental Biology, Siberian Branch, Russian Academy of Sciences, Ulan-Ude 670047, Russia; 4. Institute of Geography, Siberian Branch, Russian Academy of Sciences, Irkutsk 664033, Russia; 5. Moscow State University, Moscow 125009, Russia; 6. 中国科学院植物研究所系统与进化植物学国家重点实验室, 北京 100093

摘要: 毛莨科是真双子叶植物的基部类群之一，包含多种药用植物，具有较高的保护价值，但关于毛莨科物种多样性和谱系 多样性大尺度格局及其影响因子的研究还比较赚乏, 特别是以较高分辨率分布数据为基础的物种多样性格局研究尚未见报 道。本文旨在：(1)建立欧亚大陆东部毛莨科植物分布数据库，估算不同生活型物种多样性和谱系多样性格局，并探究格局的 形成机制。(2)分析毛莨科物种多样性和谱系多样性的相关关系, 确定多样性热点地区, 为毛莨科保护规划提供依据。根据中 国、哈萨克斯坦、吉尔吉斯斯坦、塔吉克斯坦、土库曼斯坦、乌兹别克斯坦、蒙古和俄罗斯等国家的区域和地方植物志，建 立了“欧亚大陆东部地区毛茛科物种分布数据库”。该数据库包含了欧亚大陆东部地区 1,688 种毛茛科物种的分布数据, 空间分 辨率为 $100 \mathrm{~km} \times 100 \mathrm{~km}$ 。在此基础上，估算了毛莨科全部及不同生活型的物种多样性和谱系多样性格局，并利用广义线性模 型和等级方差分离方法分析了毛莨科物种和谱系多样性格局与环境因子的关系。最后比较了物种多样性和谱系多样性的相关 关系, 确定了毛莨科的古热点地区。结果显示: (1)欧亚大陆东部毛莨科植物物种和谱系多样性均呈明显的纬度格局, 且在山 区具有较高的多样性。(2)毛茛科植物物种和谱系多样性受现代气候、地形异质性和末次冰期以来的气候变化的共同影响, 但 不同影响因子的相对贡献率在物种和谱系多样性及不同生活型之间差异显著。(3)中高纬度地区的谱系多样性高于给定物种 数的预期, 是毛茛科的古热点地区, 在毛茛科保护规划中应受到重视。

关键词: 毛莨科; 草本植物; 木本植物; 物种多样性; 谱系多样性; 生物多样性热点地区

李亦超, 陈永生, Denis Sandanov, 罗奥, 吕童, 苏香燕, 刘云鹏, 王庆刚, Viktor Chepinoga, Sergey Dudov, 王伟, 王志恒 (2021) 欧亚大陆东部毛茛科 植物多样性格局及主导因子. 生物多样性, 29, 561-574. doi: 10.17520/biods.2020246.

Li YC, Chen YS, Sandanov D, Luo A, Lü T, Su XY, Liu YP, Wang QG, Chepinoga V, Dudov S, Wang W, Wang ZH (2021) Patterns and environmental drivers of Ranunculaceae species richness and phylogenetic diversity across eastern Eurasia. Biodiversity Science, 29, 561-574. doi: 10.17520/biods.2020246.

\section{Patterns and environmental drivers of Ranunculaceae species richness and phylogenetic diversity across eastern Eurasia}

Yichao $\mathrm{Li}^{1}$, Yongsheng Chen ${ }^{\circledR 1}$, Denis Sandanov ${ }^{\circledR 3}$, Ao Luo ${ }^{1}$, Tong Lü ${ }^{\circledR 1}$, Xiangyan Su${ }^{\circledR 1}$, Yunpeng Liu ${ }^{\circledR 1}$, Qinggang Wang ${ }^{\circledR 2}$, Viktor Chepinoga ${ }^{\circledR 4}$, Sergey Dudov ${ }^{(5}$, Wei Wang ${ }^{\circledR 6}$, Zhiheng Wang ${ }^{(1 *}$

1 College of Urban and Environmental Sciences, Institute of Ecology and Key Laboratory for Earth Surface Process of the Ministry of Education, Peking University, Beijing 100871, China

2 College of Resources and Environmental Sciences and Key Laboratory of Biodiversity and Organic Farming of Beijing City, China Agricultural University, Beijing 100193, China

3 Institute of General and Experimental Biology, Siberian Branch, Russian Academy of Sciences, Ulan-Ude 670047, Russia

4 Institute of Geography, Siberian Branch, Russian Academy of Sciences, Irkutsk 664033, Russia

5 Moscow State University, Moscow 125009, Russia

6 State Key Laboratory of Systematic and Evolutionary Botany, Institute of Botany, Chinese Academy of Sciences, Beijing 100093, China

\section{ABSTRACT}

Aims: Ranunculaceae, one of the basal clades in eudicots of angiosperms, has a variety of medicinal plants and is of

收稿日期: 2020-06-15; 接受日期: 2020-07-16

基金项目: 中国科学院战略性先导科技专项(XDB31000000)、科技部重点研发计划(2017YFA06051)、国家自然科学基金(31988102; 31911530102)、 RFBR \& NSFC (19-54-53014)和 Federal Budget (0271-2021-0001 (FWSM-2021-0001))

* 通讯作者 Author for correspondence. E-mail: zhiheng.wang@pku.edu.cn 
high conservation value. However, large-scale patterns in species richness and phylogenetic diversity of Ranunculaceae based on high-resolution distribution data and their environmental determinants remain poorly understood. We aims to: (1) establish a Ranunculaceae distribution database in eastern Eurasia, estimate the species diversity and phylogenetic diversity pattern of different life forms, and explore the formation mechanism of the pattern; (2) analysis the relationship between species diversity and phylogenetic diversity of Ranunculaceae, and determine the diversity hot spots to provide basis for Ranunculaceae conservation planning.

Methods: Here, we established the first species distribution database for 1,688 Ranunculaceae species across eastern Eurasia by compiling distribution data from regional and local floral records from across China, Kazakhstan, Kyrgyzstan, Tajikistan, Turkmenistan, Uzbekistan, Mongolia, and Russia at a spatial resolution of $100 \mathrm{~km} \times 100 \mathrm{~km}$. Using this database, we mapped large-scale patterns in species richness and phylogenetic diversity for species with different life forms and explored the mechanisms underlying these patterns. We also quantified the relationship between species richness and phylogenetic diversity and identified hotspots of Ranunculaceae phylogenetic diversity.

Results: We found a latitudinal gradient in both species richness and phylogenetic diversity and revealed that Ranunculaceae in eastern Eurasia have particularly high levels of species and phylogenetic diversity in mountainous areas. Contemporary climate, habitat heterogeneity, and climate changes since the Last Glacial Maximum (LGM) all influenced spatial patterns in species richness and phylogenetic diversity, but their relative contributions varied across life forms. Phylogenetic diversity at mid and high latitudes was higher than expected when controlling for species richness, which suggests that these latitudes may represent a paleo-biodiversity hotspot of Ranunculaceae.

Conclusion: Consequently, these regions should be considered a key conservation priority for this important family.

Key words: herbaceous plants; woody plants; biodiversity hotspots; conservation; species distribution; spatial database

全球生物多样性正面临生境破坏、过度利用、 全球变化等多重威胁, 有效保护生物多样性已成为 挑战之一。物种多样性大尺度格局及其形成机制是 宏观生态学和生物地理学研究的核心问题之一 (Colwell \& Lees, 2000), 也是生物多样性保护规划 的基础(Stuart-Smith et al, 2013)。随着物种分布数据 的积累, 以往研究已对多个类群(特别是脊椎动物) 的物种多样性大尺度格局进行了较为系统的研究, 包括全球哺乳动物(Schipper et al, 2008)、两栖动物 (Fritz \& Rahbek, 2012)、鸟类(Jetz et al, 2012)和鱼类 (Rabosky，2020), 并已绘制了其全球物种多样性格 局。这些研究为全球的生物多样性保护提供了重要 的数据支撑。

种子植物是陆地植物中最为繁盛的一类, 是陆 地生态系统的优势类群。种子植物的演化显著影响 了陆生植被的演化及其对环境变化的响应(Coiffard et al, 2012; Chaboureau et al, 2014)。随着人类干扰和 利用的加剧, 大量陆生种子植物成为受威胁物种甚 至面临灭绝风险。比如, 近年来的评估显示, 全球 裸子植物中约 $40 \%$ 的物种被评估为受威胁物种(包 含易危、濒危和极危物种), 而在已完成评估的全球 被子植物中, $41 \%$ 被评估为受威胁物种 (https://www.iucnredlist.org/), 这说明全球种子植物 正面临严峻的灭绝风险。但与大型脊椎动物相比,
有关洲际至全球尺度种子植物物种多样性格局的 研究仍不足。制约种子植物物种多样性大尺度格局 研究的重要瓶颈即缺乏准确详实的物种分布数据。

物种多样性地理格局受多种因素的共同影响, 包括现代气候、生境异质性和地质历史上的气候变 化(O’Brien, 1993; Manafzadeh et al, 2017)。现代气候 (Cavender-Bares et al, 2005; Morales et al, 2013), 特 别是温度、降水和气候季节性, 对物种多样性大尺 度格局具有显著影响, 其效应被以往研究广泛证实 (Affenzeller et al, 2018; Kinlock et al, 2018)。例如, 温度和降水可通过影响植物生理过程而影响植物 分布, 过高或过低的温度和水分条件都会对植物的 生理过程产生限制, 从而限制物种的分布(Qian \& Ricklefs, 2000; Qian, 2002; 刘庆福等, 2015; 朱桂丽 等, 2017)。生境异质性可以为物种共存提供更多的 生态位, 或者为物种提供避难所 (Stein \& Kreft, 2015)。比如, 中国华中和西南山地地区的地形复杂, 为气候适应性不同的物种提供了栖息地; 同时, 自 第三纪以来, 华中和西南山地一直是植物多样性的 避难所, 保存了大量珍稀子遗植物, 如水杉 (Metasequoia glyptostroboides) 、栱桐 (Davidia involucrata) 等。此外, 在地形异质性较高的山区, 由于受人类活动影响较小, 一些山区也可以作为珍 稀物种在未来全球变化背景下的避难所(Tang et al, 
2018)。第四纪气候变化也会影响物种多样性格局, 一般认为, 第四纪气候变化更剧烈的地区可能拥有 较低的物种多样性(Fleishman et al, 2000; Currie, 2001; Kerr, 2001)。尽管以往研究已评估了不同因子 对物种多样性格局的影响, 但关于不同因子的相对 重要性及其作用在不同生活型之间的差异仍存在 争议。

木本植物和草本植物的茎内木质部发达程度 不同, 从而造成这两种不同生活型物种具有不同的 生长形态和气候生态位(Salinas \& Casas, 2007; Li et $\mathrm{al}, 2010)$ 。木本植物茎内木质部发达, 木质化组织较 多, 质地坚硬, 是大多数森林生态系统的建群种(周 乃富等, 2018)。相反, 草本植物茎内木质部不发达, 木质化组织较少, 茎干柔软, 是林下植被的重要组 成部分(Slezák \& Axmanová, 2016; Manish et al, 2017), 也是许多重要中药材的原材料(包金花等, 2018)。不同生活型的植物由于生活史策略不同, 对 环境变化的响应也不同 (Steinberg et al, 1990; Pretzsch, 2002; Massad, 2013)。一般认为, 草本植物 的生活史较短(Gebrehiwot et al, 2019), 分化速率较 高(Smith \& Donoghue 2008), 因此全球草本植物区 系在相对较近的地质历史中显示出更快的物种形 成速率(Smith \& Beaulieu, 2009; Antonelli et al, 2018)。目前, 国内外对木本植物物种多样性的大尺 度格局及其成因已进行了大量研究, 并对不同影响 因子的相对作用进行了比较(Weiser et al, 2007; 王 志恒等, 2009; Wang et al, 2012), 但有关草本植物物 种多样性格局及其成因的研究则相对较少。

生物多样性包含物种多样性、谱系多样性、功 能多样性等不同维度(Villéger et al 2017)。其中, 谱 系多样性是反映物种间系统进化关系的多样性测 度(Faith, 1994, 2016; Jones et al, 2019), 近年来被广 泛用于植物多样性分布格局的研究中(Rodrigues \& Gaston, 2002; Faith, 2013; Huang et al, 2018; Lu et al, 2018)。群落内的物种组成是进化过程和生态过程共 同作用的结果, 分析物种间亲缘关系可以反映现有 群落形成的历史过程(Rodrigues \& Gaston, 2002; Fritz \& Rahbek, 2012)。谱系多样性可在一定程度上 反映一个地区物种的分化历史和过去发生的扩散 事件对物种组成的影响 (Zhang et al, 2015; Tsirogiannis \& Sandel, 2016)。同时, 由于不同物种
的进化历史不同, 可能对现代气候产生不同的适应, 因此即使物种数量相同的群落, 由于其组成物种的 进化历史、祖先生态位及环境适应性不同, 群落对 未来气候变化的响应也可能存在差异(Faith, 1992; Zhu et al, 2006; López-Pujol et al, 2011b)。也正是因 为这样的原因, 越来越多的研究提出, 保护生物多 样性不应只考虑物种多样性, 还要考虑谱系多样性 (陈之端和李德铢, 2018; Miller et al, 2018)。在具有 较高谱系多样性的地区建立保护区可以更好地保 留物种的进化特征和进化潜力。近期研究已开始关 注谱系多样性的研究。比如, 基于山地植物群落的 研究显示, 群落谱系多样性沿海拔梯度呈升高、降 低或单峰型的变化趋势(Zhu et al, 2019; Zu et al, 2019); 而在洲际至全球尺度, 人们发现北美地区植 物(Qian et al, 2017; Mishler et al, 2020)和全球两栖 类(Fritz \& Rahbek, 2012)的谱系多样性格局均呈明 显的纬度格局, 且与物种多样性呈显著正相关。然 而, 有关东亚地区植物谱系多样性大尺度格局的研 究仍然不足, 制约了基于谱系多样性的植物多样性 保护规划(Kareiva \& Marvier, 2003; Zhang, 2015)。

毛莨科是真双子叶植物的基部类群之一, 包含 多种药用植物, 具有较高的保护价值( Li et al, 2020)。毛茛科绝大多数物种是一年生、两年生或多 年生草本植物(Wang et al, 2016), 全球共有约2,300 多种, 其中约 $2 / 3$ 的物种分布在亚洲温带地区 (Chanderbali et al, 2016; Sramkó et al, 2019)。作为被 子植物早期分化的类群之一, 毛莨科可能起源于白 严纪早期的温带地区(Ziman \& Keener, 1989; Tamura, 1995), 后在亚洲温带地区特别是青藏高原 东南部地区经历快速分化(Kong et al, 2017)。因此, 毛茛科是北半球高山生态系统的重要组成成分 (Ziman, \& Keener, 1989; Tamura, 1995), 对温带山 地植物区系和植被的演化具有重要作用。探索毛莨 科植物物种多样性的大尺度格局及其形成机制可 以为该科物种多样性保护政策的制定提供数据和 理论支撑。然而, 关于毛莨科物种多样性和谱系多 样性大尺度格局及其影响因子的研究还比较贵乏, 特别是以较高分辨率分布数据为基础的物种多样 性格局研究尚未见报道。基于以上背景, 我们提出 了以下问题: (1)毛茛科物种多样性和谱系多样性格 局如何? 相关关系如何? 主导因子是什么? (2)现代 
气候、过去气候变化和地形异质性对毛茛科物种多 样性的相对贡献如何? 在木本植物和草本植物之 间是否有区别?

\section{材料与方法}

\section{1 物种分布数据}

利用中国、哈萨克斯坦、吉尔吉斯斯坦、塔吉 克斯坦、土库曼斯坦、乌兹别克斯坦、蒙古和俄罗 斯等国家公开的大量区域和地方植物志书, 建立了 “欧亚大陆东部地区毛茛科植物物种分布数据库” (完整的数据源清单见附录1)。中国物种分布的数据 来源均为县级, 其他国家分布数据的分辨率均低于 $100 \mathrm{~km} \times 100 \mathrm{~km}$ 。我们进一步从提供标本记录的在 线数据库中收集了物种的分布数据, 包括2019年5 月访问的“国家标本资源共享平台” (NSII, http://www.nsii.org.cn)、“全球生物多样性信息网络” (GBIF, http://www.gbif.org/)等。

数字化后, 数据源中的物种分布记录可以分为 点和面两种格式。由于上述地区和地方出版物中原 始地理单元的中值接近100 km $\times 100 \mathrm{~km}$, 因此在 ArcGIS 10.3中, 将分布图转换为具有 $100 \mathrm{~km} \times 100$ $\mathrm{km}$ 空间分辨率的环行投影网格(cyclinder)的分布, 然后分别按点和面对结果进行整合。删除面格式的 重复并叠加数据后, 然后将面格式的结果与点格式 的数据汇总。以Catalogue of Life (http://www.catalo geoflife.org)为准对来自不同数据源的物种名称进 行校准, 删除栽培种和外来种的记录, 并将亚种单 位(即亚种和变种)合并为种。

采集到的植物分为两种生活型：木本(包括灌 木、矮生灌木、亚灌木和木质藤本植物)和草本(包 括草本和草质藤本植物)。生活型数据从已发表的植 物区系和在线数据库中收集, 包括The Tropicos (http://www.tropicos.org/Home.aspx) 、 eFloras.org (http://www.efloras.org/project_list.aspx) 、 Scientific Database of China Plant Species (http://db. kib.ac.cn/e flora/Default.aspx)和Chinese Plant Subject Databases (http://www.plant.csdb.cn)。最终收集到毛茛科植物 1,688 种, 隶属于 49 属, 其中草本植物 1,398 种, 木本 植物151种。

谱系多样性的计算采用Faith谱系多样性的方 法(Faith, 1994), 即最小生成树的总支长。其计算通 过R软件的picante程序包完成。由于当前全球毛茛
科种级系统发育树尚未成功构建, 因此本文中使用 了Wang等(2016)建立的全球毛茛科属级系统发育 树。Wang等(2016)对全球76种毛莨科植物进行取样, 并对 5 个质体基因 $(r b c \mathrm{~L}, m a t \mathrm{~K}, a t p \mathrm{~B}, a t p \mathrm{~A}, n d h \mathrm{~F})$ 和1 个核基因(26S rDNA)进行测序; 在此基础上, 利用 贝叶斯方法建立了毛茛科属级系统发育树, 并利用 该科3块化石对系统发育树进行了定年。该属级系 统进化树涵盖全球毛茛科55属中的50属(占比约 91\%), 很好地覆盖了毛茛科各主要分支。可见, 该 系统进化树在属级水平的采样率较高, 取样的区域 偏差较小。利用该属级系统进化树，根据毛莨科物 种的属级分类系统, 我们将研究区内的毛茛科物种 以属基部多歧分支的形式插入所属的属级分支内; 然后利用这一系统进化树计算全部毛茛科植物和 草本植物的谱系多样性格局。这一方法已在以往研 究中被广泛使用(如Lu et al, 2018)。由于本研究中, 毛莨科木本植物只包含铁线莲属(Clematis) (部分为 木质藤本), 而我们使用的系统发育树为属级树, 难 以反映属内的种间关系, 因此文中没有计算木本植 物的谱系多样性。

\section{2 环境数据}

本文使用的气候数据来自 WorldClim (http://www.worldclim.org), 空间分辨率为 2.5 。使用 ArcGIS 10.3计算每个网格的气候平均值, 并将现代 气候因子分为 3 类: (1)温度变量, 包括年均温(MAT) 和最冷季均温(月均温最低的连续 3 个月, 在本研究 区一般为 12 月至次年2月, MTCQ)。MAT在以往的研 究中被广泛用于表征环境能量, MTCQ用于研究冬 季低温对物种多样性的影响。O'Brien (1993)对非洲 木本植物和Wang等(2011)对中国木本植物多样性的 研究均发现, 冬季温度对木本植物物种多样性有显 著影响。(2)降水变量, 包括年平均降水量(MAP)和 最干季降水量(月降水量最低的连续3个月的降水量, PDQ)。PDQ反映了旱季降水的影响。Huang等(2015) 研究认为, 冬季降水对中国的子遗植物有显著影 响。(3)气候季节性, 包括温度季节性(一年内月平均 气温的标准差, TSN)和降水季节性(一年内月降水 量的变化系数, PSN)。TSN和PSN反映了气温和降水 季节变化的影响, 是气候异质性的指标。

用网格内的海拔高差(ELER)反映生境异质性。 海拔高差即一个网格内最高海拔与最低海拔的差。 海拔数据来源于美国地质勘探局(https://www.usgs. 
gov/)的GTOPO数据, 空间分辨率为 $1 \mathrm{~km} \times 1 \mathrm{~km}$ 。利 用ArcGIS 10.3计算每个100 km $\times 100 \mathrm{~km}$ 网格单元 内的海拔高差。

第四纪气候变化以末次冰期(LGM, 约公元前 22,000前)以来的温度变化速率(即物种跟踪气候变 化所必须的空间迁移距离)来衡量, 是自末次盛冰 期以来年均温变化的时间梯度和年均温变化的空 间梯度之间的比率(Loarie et al, 2009), 一般认为, 末次冰期以来的气候变化强弱能较好地反映第四 纪时期不同地区气候波动的程度(Araújo et al, 2008; Sandel et al, 2011)。由于第四纪古气候数据的全球 模拟尚未完成, 以往研究通常用末次冰期以来的气 候变化来反映第四纪气候波动。在本文中, 末次冰 期时的气候数据采用MPI-ESM-P模型(Watanabe et al, 2011)的重建结果。

\section{3 分析方法}

利用欧亚大陆全部1,688种毛莨科的物种分布 数据, 结合系统发育树数据, 估算欧亚大陆毛茛科 全部物种、草本植物和木本植物的物种多样性和谱 系多样性, 并用ArcGIS 10.3绘制格局图, 其中, 物 种多样性以每个网格内的物种数表示。使用一元线 性最小二乘回归模型(ordinary least square models, OLS models)拟合谱系多样性与物种多样性的关系, 然后计算二者模型的残差(实际值与预测值之间的 差值)并绘制残差格局图。

绘制物种多样性和谱系多样性与环境因子之 间的散点图。再利用一元广义线性模型(generalized linear models, GLMs)中的泊松回归分析物种多样性 与环境因子之间的关系; 利用一元线性最小二乘回 归模型分析谱系多样性与环境因子之间的关系。每 个变量对物种多样性或谱系多样性格局的解释率 以相应GLM或OLS模型的 $R^{2}$ 进行衡量。为了消除空 间自相关对模型显著性 $(P$ 值)的影响, 在模型显著 性检验中使用修正 $t$ 检验(Clifford et al, 1989); 只有 当校正后的 $P<0.05$ 时, 才认为GLM和OLS模型的 $R^{2}$ 显著。

对包含 2 个变量的环境变量类别, 以其中解释 率最高的因子反映该类别变量的作用, 用于多元回 归分析。初步结果显示, 年平均降水量、最冷季平 均气温、气温季节性分别是水分、能量、气候季节 性变量中解释率最高的变量, 可用来反映这些类别 变量的作用。采用等级方差分离模型(hierarchical partitioning) (Mac Nally, 2000)分析各变量对物种多 样性和谱系多样性的独立、共同解释率。等级方差 分离模型采用 $\mathrm{R}$ 软件中的hier.part程序包完成。

\section{2 结果}

\section{1 物种多样性和谱系多样性格局及其关系}

欧亚大陆东部毛茛科全部物种、木本植物和草 本植物的物种多样性呈明显的纬度梯度格局, 随着 纬度的增加, 物种多样性逐渐降低。全部物种和草 本植物的物种多样性在云贵高原、川桂交界、秦巴 山区等山区最多(图1a、c), 而木本植物物种多样性 在横断山区、云南南部、云贵高原、川桂交界、秦 巴山区等山区最高(图1b)。

全部物种谱系多样性与物种多样性格局有所 不同, 除了低纬度地区谱系多样性较高之外, 中高 纬度地区也有较高的谱系多样性(图1d)。草本植物 谱系多样性的地理格局与物种多样性格局较为相 似，在云贵高原、秦巴山区较高(图1e)。

谱系多样性与全部物种和草本植物物种多样 性均呈现较强的正相关关系(图2a、c)。物种与谱系 多样性关系的残差格局图显示, 对于全部物种, 残 差在中高纬度地区为正值(图2b), 对于草本植物, 残差在低纬度地区为正值(图2d)。这说明, 这些地区 的谱系多样性高于给定物种多样性时的预期。

\section{2 物种多样性和谱系多样性的影响因子}

一元广义线性模型模拟结果表明, 在所有环境 因子中, 温度季节性是木本植物物种多样性格局的 主导因子, 且其对木本植物的解释率高于草本植物 (图3)。在温度季节性弱的地区, 物种多样性较高(图 3)。全部物种和草本植物物种多样性格局的主导因 子是末次冰期以来的气候变化速率, 且其对草本植 物的解释率高于木本植物(图3)。在末次冰期以来气 候变化较小的地区, 物种多样性较高(图3)。地形异 质性对不同生活型物种多样性均具有显著影响, 在 地形异质性较高的地区, 物种多样性较高(图3)。等 级方差分离结果与一元广义线性模型拟合结果一 致, 末次冰期以来的气候变化速率对全部物种、草 本植物物种多样性的独立解释率和总解释率(共同 解释率和独立解释率之和) 最高, 温度季节性对木 本植物物种多样性的总解释率最高(图4)。 
(a)

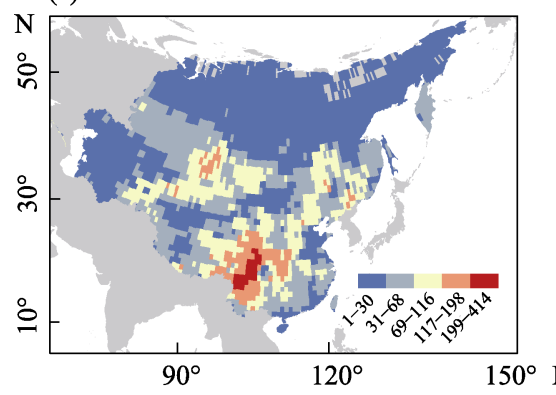

(b)

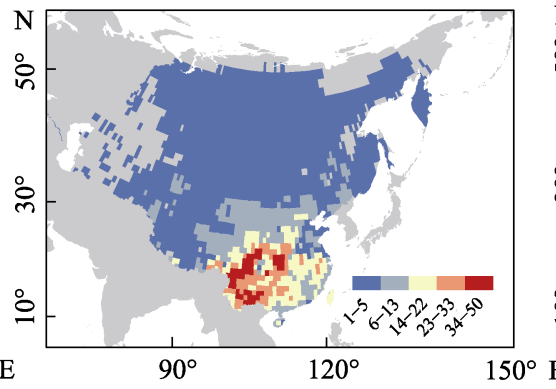

(c)

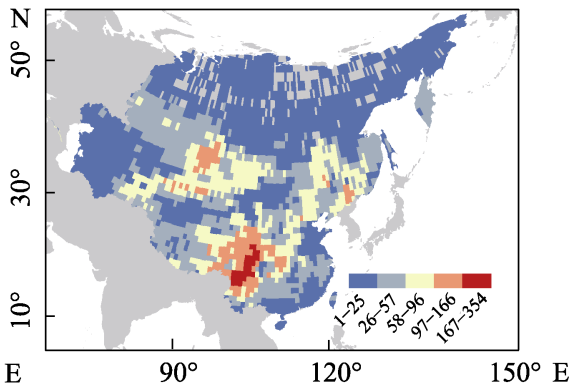

(d)

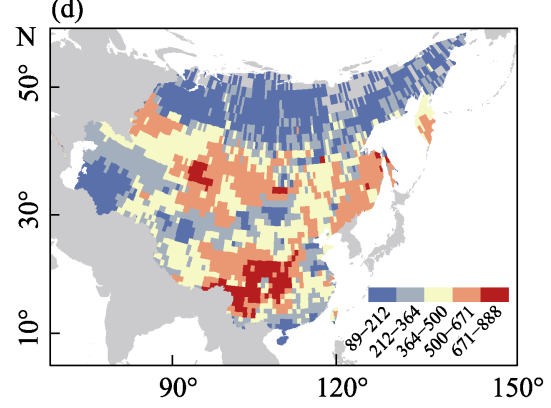

(e)

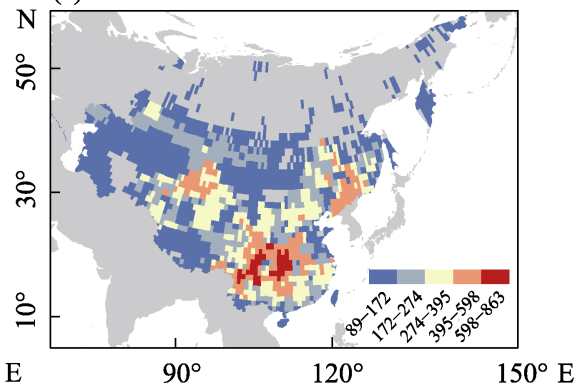

图1 欧亚大陆东部毛莨科全部物种(a)、木本植物(b)、草本植物(c)物种多样性及全部物种(d)、草本植物(e)谱系多样性格局 Fig. 1 Geographical patterns in the species richness of all Ranunculaceae species (a), woody species (b), and herbaceous species (c); phylogenetic diversity of all Ranunculaceae species (d) and woody species (e) in East Eurasia estimated in cyclinder grids of $100 \mathrm{~km}$ $\times 100 \mathrm{~km}$

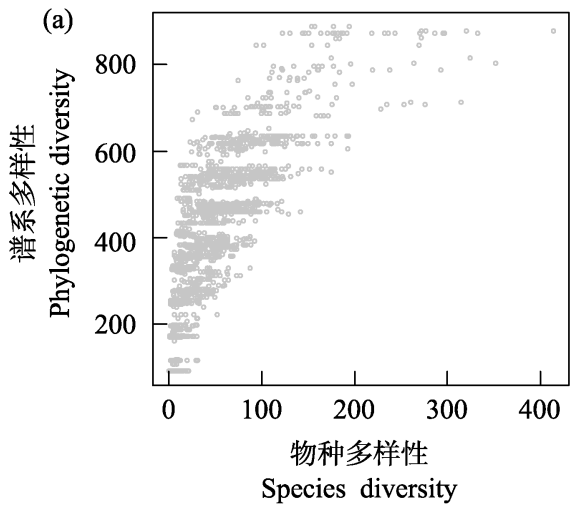

(b)

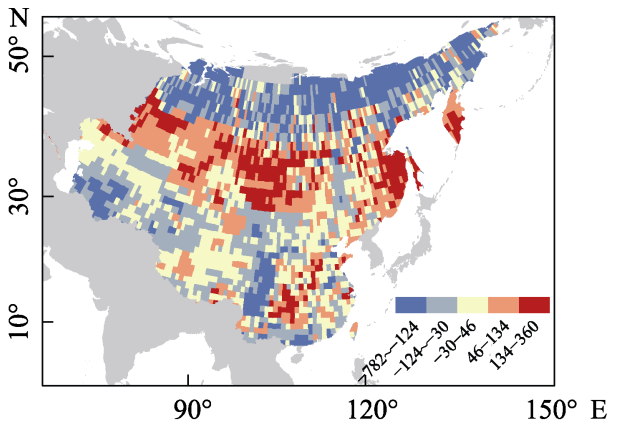

(d)

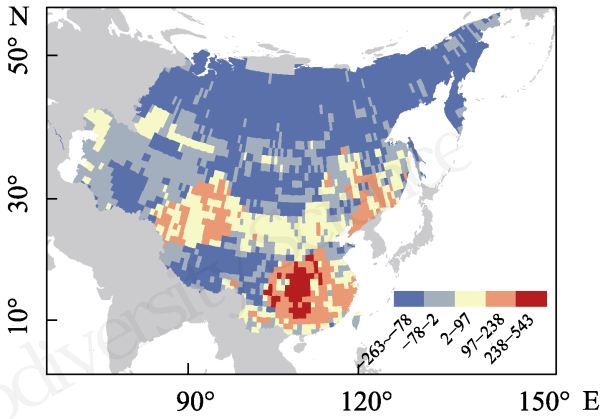

图2 欧亚大陆东部毛莨科谱系多样性与全部物种和草本植物物种多样性的关系(a, c)及残差格局图(b, d)

Fig. 2 The relationship between phylogenetic diversity and species diversity of all Ranunculaceae species (a) and herbaceous (c) species and their residual patterns (b, d) in East Eurasia 
一元最小二乘回归模型拟合结果表明, 末次冰 期以来的气候变化速率是全部物种谱系多样性格 局的主导因子, 在末次冰期以来气候变化较小的地 区, 谱系多样性较高(图3)。旱季降水是草本植物谱 系多样性格局的主导因子, 在旱季降水较多的地区, 谱系多样性较高(图3)。等级方差分离结果与一元广 义线性模型拟合结果一致, 末次冰期以来的气候变 化速率对全部物种谱系多样性的独立解释率和总 解释率最高, 旱季降水对草本植物谱系多样性的独 立解释率最高(图4)。

\section{3 讨论}

\section{1 毛莨科物种多样性和谱系多样性格局及其影} 响因子

欧亚大陆东部毛莨科全部物种的物种多样性 和谱系多样性均呈现明显的纬度格局(图 1a、d), 且 二者呈显著正相关关系, 这与以往有关植物和两栖
类多样性的研究结果一致(Rodrigues \& Gaston, 2002; Fritz \& Rahbek, 2012)。末次冰期以来的气候 变化是全部植物物种多样性和谱系多样性格局的 主导因子, 在末次冰期以来气候变化较小的地区多 样性较高, 这与以往的研究结果也是一致的 (López-Pujol et al, 2011b; Antonelli et al, 2018; Muellner-Riehl et al, 2019)。与本文结果一致, 对中 亚地区木本植物狭域种(Liu et al, 2019)以及欧洲乔 木(Svenning \& Skov, 2007)的研究均发现, 末次冰 期以来的气候变化显著影响了物种多样性格局。第 四纪以来冰期和间冰期的反复交替，特别是末次冰 期以来气候的剧烈变化，使得全球很多地区的植被 分布发生改变(Wang SY et al, 2017; Li et al, 2019; 邱浩杰等, 2020)。研究显示, 第四纪特别是末次冰 期以来气候变化较小的地区(也即气候较稳定的地 区)为物种提供了重要的避难所，使得大量古老子 遗类群得以保存，从而提高这些地区的谱系多样性
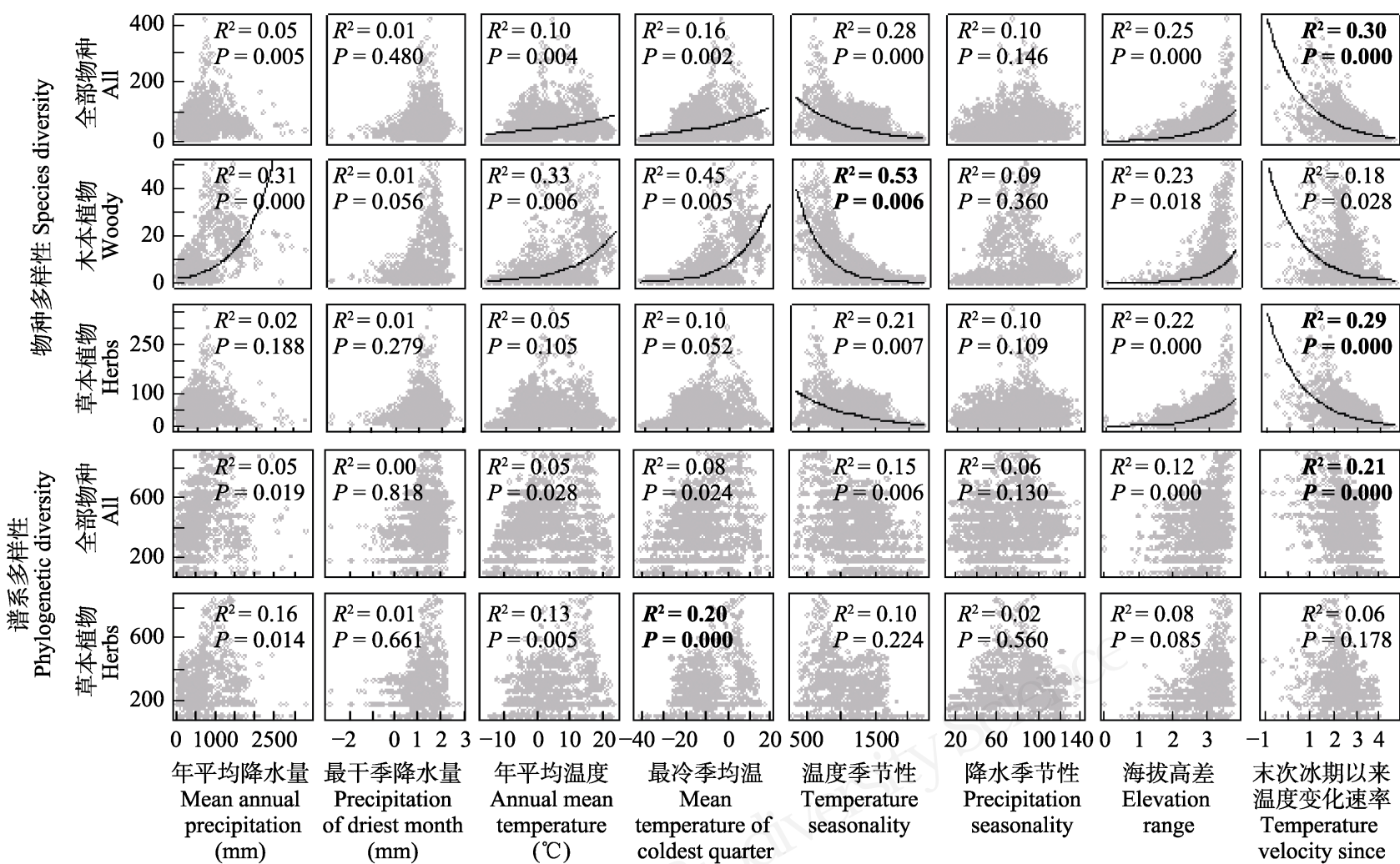

temperature

$\left({ }^{\circ} \mathrm{C}\right)$

temperature of seasonality

降水季节性

Precipitation 海拔高差

$\begin{array}{lllll}-1 & 1 & 2 & 3 & 4\end{array}$

seasonality

Elevation 末次冰期以来 温度变化速率 Temperature velocity since the LGM

图3 欧亚大陆东部毛莨科全部物种、木本植物、草本植物物种多样性及全部物种和草本植物谱系多样性与现代气候、海拔 高差和过去气候变化的关系散点图, 加粗的数值表示一行中 $\boldsymbol{R}^{2}$ 最大的数值。

Fig. 3 The relationship between the richness of all Ranunculaceae species, woody species, and herbaceous species; and the phylogenetic diversity of all Ranunculaceae species and herbaceous species in East Eurasia and contemporary climate, elevation range, past climate change evaluated by generalized linear models, the value in bold indicates the maximum value of $R^{2}$ in a row. 

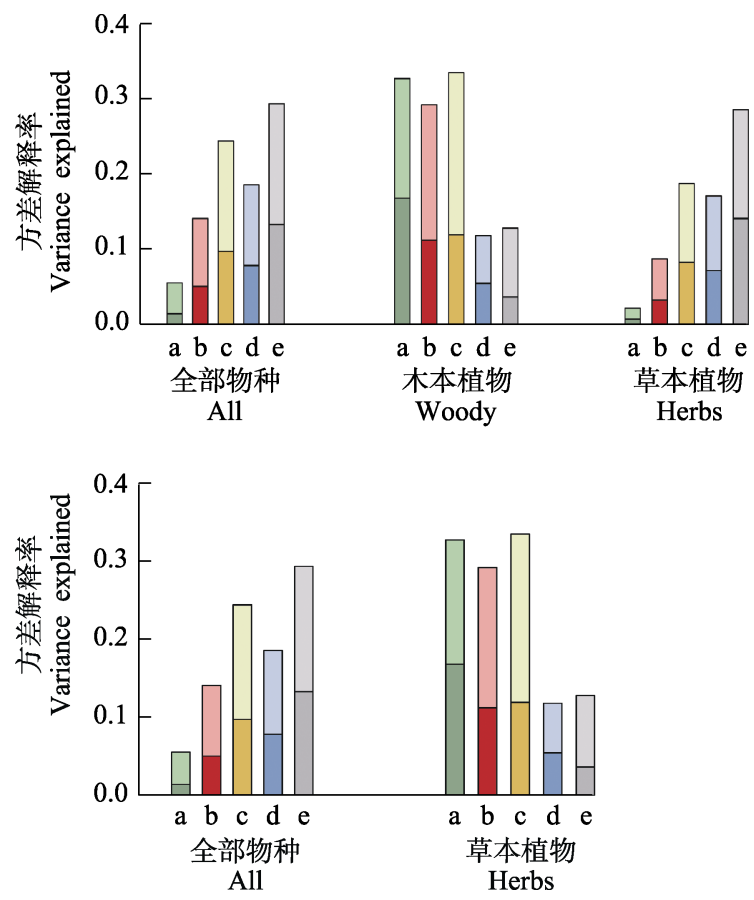

图4 现代气候、海拔高差和过去气候变化对欧亚大陆东部 毛莨科全部物种、木本植物和草本植物丰富度和谱系多样性 的影响。图中显示了物种多样性和各类影响因子之间的等级 方差分离结果。不同柱子分别代表 5 个不同的解释因子, 分 别代表水分(a)、能量(b)、温度季节性(c)、海拔高差(d)和末 次冰期以来的温度变化速率(e)。深色表示独立解释量, 浅色 表示共同解释量。

Fig. 4 The effects of contemporary climate, elevation range and past climate change on species richness and phylogenetic diversity of all Ranunculaceae species, woody specie, herbaceous species in East Eurasia. The figure shows the results of hierarchical partitioning between species richness and each selected dominant factor. Different charts respectively represent five different explanatory factors, namely, water (a), energy (b), temperature seasonality (c), elevation range (d) and temperature velocity since the Last Glacial Maximum (LGM) (e). The dark color means independent effect, light color means joint effects.

(Dupont-Nivet et al, 2007; Araújo \& Rahbek, 2008; López-Pujol et al, 2011a; Sandel et al, 2011)。相反, 在第四纪气候波动较大的地区, 物种易发生局地灭 绝; 同时, 较大的第四纪气候波动可能也使得部分 类群进化较快, 从而更易形成物种年轻且末端支长 较短的分支(Weir et al, 2007); 这两个过程可能均使 得第四纪气候变化剧烈地区的谱系多样性较低。这 在一定程度上解释了毛茛科以及其他类群(如欧洲 乔木, Skov \& Svenning, 2004; 欧洲两栖和爬行动物, Araújo et al, 2008)物种多样性与末次冰期以来气候 变化间的显著负相关关系。
此外, 以往研究发现, 亲缘关系相近的物种也 倾向于具有相同的气候适应性，也即气候生态位的 谱系保守性(Li et al, 2020)。气候变化倾向于将亲缘 关系较近、生态位相似的物种笁选进入特定群落, 使得气候变化较大地区的植物群落通常具有较低 的谱系多样性, 这也可能使得谱系多样性与末次冰 期以来的气候变化幅度间呈显著负相关。在更长的 地质历史时间尺度, 气候变化也可能通过影响物种 的分化过程而影响物种多样性格局。比如, 近期研 究显示, 中新世以来的气候变化, 特别是中新世中 期以来的全球性变冷、变干趋势显著促进了壳斗 科、桤木属(Alnus)植物类群在东亚亚热带的快速分 化(Zhang et al, 2014; Xu et al, 2016), 进而提高了东 亚温带和亚热带木本植物物种多样性。

本研究发现, 在物种多样性和谱系多样性格局 的影响因子中, 温度和降水的作用不显著, 这与以 往的研究结果有所不同。比如, 在中国, 最冷季均 温是影响木本植物物种多样性地理格局的主要因 素(Sakai \& Malla, 1981; Wang et al, 2012), 这主要 是因为中国木本植物区系中含有较多的热带和亚 热带植物区系成分(Fang \& Yoda, 1988, 1989), 而这 些植物对冬季低温非常敏感(Feldmane et al, 2016), 冬季低温通过限制热带和亚热带物种向北扩散而 形成了当前的多样性格局(Wang et al, 2011)。再如， 水分因子对于中国蓄薇科植物的物种多样性格局 也具有较强的作用。蓄薇科可能起源于东亚温带地 区，由于有倾向于保留其祖先温带生态位的趋势， 对寒冷的耐受性较强, 因而冬季低温对其物种多样 性影响较弱; 与温度相比, 水分因子对蓄薇科物种 多样性的影响相对较强(邹东廷等, 2019)。而对毛茛 科系统发育的研究显示, 毛茛科起源于温带, 并在 北半球温带和寒温带地区广泛分布 (Ziman \& Keener, 1989; Tamura, 1995; Anderson et al, 2005), 对冬季低温和干旱环境具有较强的适应性, 这可能 部分解释了为什么冬季低温和年平均降水对毛茛 科物种多样性和谱系多样性的作用均较弱。

\section{2 不同生活型间物种多样性格局影响因子的差异}

欧亚大陆东部毛茛科木本和草本植物的物种 多样性格局不同: 木本植物主要集中分布在低纬度 地区，而草本植物分布更为广泛; 在中高纬度地区， 草本植物的物种多样性高于木本植物(图1b、c)。木 
本植物和草本植物物种多样性格局的差异可能主 要是由两类生活型不同的生活史策略和环境适应 性引起的(Ferreira Ribeiro\& Tabarelli, 2002)。一般来 说, 草本植物的生活史比木本植物短, 因此对气候 变化的敏感性比木本植物强(Francis \& Currie, 1998; Smith \& Beaulieu, 2009; Song et al, 2019)。

末次冰期以来的气候变化对木本植物物种多 样性的影响弱于其对草本植物物种多样性的影响, 这主要是因为草本植物的世代时间通常比木本植 物更短, 因而可能拥有更高的进化速率(Smith \& Donoghue, 2008; Qi et al, 2014), 而这又使得草本植 物拥有较快的微进化适应(Hof et al, 2011; Liu et al, 2019), 使得其适应过去气候变化的滞后时间缩短 了(Smith \& Donoghue, 2008; Smith \& Beaulieu, 2009)。由于草本植物生活史较短, 草本植物可以快 速适应新环境(Albuquerque et al, 2011; Liu et al, 2019), 因此对过去气候变化十分敏感。此外, 由于 毛茛科木本植物主要分布在中国南部地区, 而这一 区域在第四纪气候波动中一直是物种保存的避难 所, 这可能也是末次冰期以来的气候变化对木本植 物的影响弱于草本植物的原因之一。

地形异质性对木本植物和草本植物的影响都 很显著。山区地形异质性和生境破碎化程度高, 复 杂的生境除了为物种提供更多生态位之外, 还可以 通过促进异域物种形成和生态成种过程, 促进新物 种的形成(Xing \& Ree, 2017)。但在两种生活型间, 地形异质性对木本植物物种多样性的影响强于其 对草本植物物种多样性的影响, 这可能是由于地形 异质性对于木本植物和草本植物的影响存在尺度 依赖性(Hurlbert \& Jetz, 2007)。草本植物由于形态低 矮, 林下分布居多, 更容易受到土壤湿度、光照强 度等微地形环境因素的影响, 并且与动物运输种 子、人类干扰等生物因素也密切相关(Martínez, 2003; Saul-Tcherkas \& Steinberger, 2011; Song et al, 2011)。虽然微地形因子在较小的空间尺度中对物种 多样性具有较显著影响, 但随着空间尺度的增加, 微地形因子的作用逐渐变弱甚至被其他因子的作 用所掩盖。

无论对于木本植物还是草本植物, GLMs 结果 都表明, 温度季节性对毛茛科物种多样性具有较强 作用。在温度季节性强的地区, 平均气温在一年内
变化剧烈(Liu et al, 2019; 邹东廷等, 2019), 对植物 的生理活动和生长造成影响, 从而限制植物分布和 物种多样性(Jacquemyn et al, 2001; Roscher et al, 2009; Hettenbergerová et al, 2013)。

\section{3 生物多样性热点地区分析}

本研究显示, 位于中国的云贵高原、川桂交界 山区、秦巴山区等山区是毛茛科物种多样性和谱系 多样性的热点地区。这些结果说明, 毛茛科的多样 性热点地区多集中在山区, 这与以往基于其他类群 的研究结果一致(Wang QG et al, 2017; Antonelli et al, 2018; Muellner-Riehl et al, 2019)。这可能是由于 这些地区巨大的生境异质性所导致。山脉的隆起会 给这些地区带来复杂的地形和多样的生境, 为毛茛 科植物的分布提供更加多样的生存环境, 从而容纳 更多的物种共存(López-Pujol et al, 2011b; Antonelli et al, 2018; 邹东廷等, 2019)。同时, 复杂地形导致 的较高的物种分化速率可能也是该地区形成毛茛 科生物多样性热点的原因之一。

以往的研究表明, 物种多样性、谱系多样性的 热点地区可能表现出不同的空间分布特征(Tucker \& Cadotte, 2013)。在确定保护优先区时, 为了保护 生物多样性的不同维度, 不应只考虑物种多样性, 也要考虑谱系多样性(Kareiva \& Marvier, 2003; Zhang et al, 2015)。根据谱系多样性格局以及物种多 样性和谱系多样性关系的残差图可知, 对于毛茛科 全部物种而言, 中高纬度地区的谱系多样性较高, 残差也较高, 说明这些地区的谱系多样性高于具有 相同物种数的其他地区。这可能在一定程度上说明, 这些地区保存了毛莨科物种独特的进化历史 (Kareiva \& Marvier, 2003)。一旦这些进化历史丢失, 将会造成某些独立支系的消失, 在生物多样性保护 方面造成巨大损失(Faith, 1992)。化石和分子谱系研 究显示, 毛茛科起源于白严纪的温带地区(Tamura, 1995; Ziman \& Keener, 1989), 后在欧亚大陆东部中 高纬度的亚洲温带地区快速分化并向周边扩散。因 此, 欧亚大陆中高纬度地区可能是毛茛科的古热点 地区(Cai et al, 2021), 这一地区的毛茛科物种应在 该科物种的保护规划种得到重视。

对于草本植物而言, 低纬度地区的谱系多样性 较高, 残差也比较高, 这与物种多样性格局较为相 似。具体而言, 草本植物谱系多样性高的地区多集 
中在山区。在地质历史进程中, 山脉隆起带来的复 杂地形除了提供多种生境外, 更促进了物种快速分 化并改变了群落物种组成(Chaieb et al, 2019), 从而 表现出更高的谱系多样性。

欧亚大陆东部毛茛科植物物种多样性、谱系多 样性均呈明显的纬度梯度格局, 由南向北逐渐降低, 在山区具有较高的多样性。毛茛科植物物种和谱系 多样性受现代气候、地形异质性和末次冰期以来的 气候变化影响, 但不同影响因子的相对作用在物种 和谱系多样性之间以及在不同生活型之间差异显 著。在所有因子中, 末次冰期以来的气候变化对欧 亚东部毛茛科植物物种和谱系多样性的影响最强, 且对草本植物多样性的影响大于木本植物; 现代气 候对木本植物分布的影响大于草本植物。地形异质 性对不同生活型物种多样性均具有显著影响。我们 发现, 在中高纬度地区, 毛莨科的谱系多样性高于 具有相同物种数的其他地区，说明这些地区保存了 毛莨科物种独特的进化历史。为保护毛莨科的进化 历史, 这些地区在该科的保护规划中应得到重视。

\section{ORCID}

陈永生 (10) https://orcid.org/0000-0001-5835-8249

Denis Sandanov (ID https://orcid.org/0000-0002-8504-3485

吕童 (D) https://orcid.org/0000-0002-5925-0608

苏香燕 (D) https://orcid.org/0000-0003-0093-077X

刘云鹏 (iD https://orcid.org/0000-0001-6188-3511

王庆刚 (iD https://orcid.org/0000-0002-3975-1560

Viktor Chepinoga (D) https://orcid.org/0000-0003-3809-7453

Sergey Dudov (D) https://orcid.org/0000-0003-1512-0956

王伟 (D) https://orcid.org/0000-0001-6901-6375

王志恒 (iD) https://orcid.org/0000-0003-0808-7780

\section{参考文献}

Affenzeller M, Kadereit JW, Comes HP (2018) Parallel bursts of recent and rapid radiation in the Mediterranean and Eritreo-Arabian biodiversity hotspots as revealed by Globularia and Campylanthus (Plantaginaceae). Journal of Biogeography, 45, 552-566.

Albuquerque FS, Olalla-Tárraga MÁ, Montoya D, Rodríguez MÁ (2011) Environmental determinants of woody and herb plant species richness patterns in Great Britain. Écoscience, 18, 394-401.

Anderson CL, Bremer K, Friis EM (2005) Dating phylogenetically basal eudicots using $r b c \mathrm{~L}$ sequences and multiple fossil reference points. American Journal of Botany, 92, 1737-1748.

Antonelli A, Kissling WD, Flantua SGA, Bermúdez MA, Mulch A, Muellner-Riehl AN, Kreft H, Linder HP, Badgley
C, Fjeldså J, Fritz SA, Rahbek C, Herman F, Hooghiemstra H, Hoorn C (2018) Geological and climatic influences on mountain biodiversity. Nature Geoscience, 11, 718-725.

Araújo MB, Nogués-Bravo D, Diniz-Filho JAF, Haywood AM, Valdes PJ, Rahbek C (2008) Quaternary climate changes explain diversity among reptiles and amphibians. Ecography, 31, 8-15.

Bao JH, Hong Y, Li XX, Jia JY, Yang HS, Ao WLJ (2018) Wild Mongolian medicine resources and utilization of Ranunculaceae in Horqin sandy land. Lishizhen Medicine and Materia Medica Research, 29, 699-701. (in Chinese) [包金花, 红艳, 李旭新, 贾俊英, 杨恒山, 奥·乌力吉 (2018) 科尔沈沙地毛莨科野生蒙药植物资源及其利用. 时珍国医国药, 29, 699-701.]

Cai HY, Lyu LS, Shrestha N, Tang ZY, Su XY, Xu XT, Dimitrov D, Wang ZH (2021) Geographical patterns in phylogenetic diversity of Chinese woody plants and its application for conservation planning. Diversity and Distributions, 27, 179-194.

Cavender-Bares J, Cortes P, Rambal S, Joffre R, Miles B, Rocheteau A (2005) Summer and winter sensitivity of leaves and xylem to minimum freezing temperatures: A comparison of co-occurring Mediterranean oaks that differ in leaf lifespan. New Phytologist, 168, 597-612.

Chaboureau AC, Sepulchre P, Donnadieu Y, Franc A (2014) Tectonic-driven climate change and the diversification of angiosperms. Proceedings of the National Academy of Sciences, USA, 111, 14066-14070.

Chanderbali AS, Berger BA, Howarth DG, Soltis PS, Soltis DE (2016) Evolving ideas on the origin and evolution of flowers: New perspectives in the genomic era. Genetics, 202, 1255-1265.

Chaieb G, Abdelly C, Michalet R (2019) Interactive effects of climate and topography on soil salinity and vegetation zonation in North African continental saline depressions. Journal of Vegetation Science, 30, 312-321.

Chen ZD, Li DZ (2018) Phylogenetic diversity and biodiversity conservation. Kexue, 70, 2225. (in Chinese) [ 陈之端, 李 德铢 (2018) 系统发育多样性和生物多样性保护. 科学. 70, 22-25. ]

Clifford P, Richardson S, Hémon D (1989) Assessing the significance of the correlation between two spatial processes. Biometrics, 45, 123-134.

Colwell RK, Lees DC (2000) The mid-domain effect: Geometric constraints on the geography of species richness. Trends in Ecology and Evolution, 15, 70-76.

Coiffard C, Gomez B, Daviero-Gomez V, Dilcher DL (2012) Rise to dominance of angiosperm pioneers in European Cretaceous environments. Proceedings of the National Academy of Sciences, USA, 109, 20955-20959.

Currie DJ (2001) Projected effects of climate change on patterns of vertebrate and tree species richness in the conterminous United States. Ecosystems, 4, 216-225. 
Dupont-Nivet G, Krijgsman W, Langereis CG, Abels HA, Dai S, Fang X (2007) Tibetan Plateau aridification linked to global cooling at the Eocene-Oligocene transition. Nature, 445, 635-638.

Faith DP (1992) Systematics and conservation: On predicting the feature diversity of subsets of taxa. Cladistics, 8, 361-373.

Faith DP (1994) Phylogenetic pattern and the quantification of organismal biodiversity. Philosophical Transactions of the Royal Society of London Series B, Biological Sciences, 345, 45-58.

Faith DP (2013) Biodiversity and evolutionary history: Useful extensions of the PD phylogenetic diversity assessment framework. Annals of the New York Academy of Sciences, 1289, 69-89.

Faith DP (2016) The PD phylogenetic diversity framework: Linking evolutionary history to feature diversity for biodiversity conservation. In: Biodiversity Conservation and Phylogenetic Systematics (eds Pellens R, Grandcolas P). Springer, Cham.

Fang JY, Yoda K (1988) Climate and vegetation in China (I). Changes in the altitudinal lapse rate of temperature and distribution of sea level temperature. Ecological Research, 3, 37-51.

Fang JY, Yoda K (1989) Climate and vegetation in China (II). Distribution of main vegetation types and thermal climate. Ecological Research, 4, 71-83.

Feldmane D, Ruisa S, Rubauskis E, Kaufmane E (2016) Winter hardiness of sour cherries influenced by cultivar and soil moisture treatment. Acta Horticulturae, 1130, 111-116.

Ferreira Ribeiro L, Tabarelli M (2002) A structural gradient in Cerrado vegetation of Brazil: Changes in woody plant density, species richness, life history and plant composition. Journal of Tropical Ecology, 18, 775-794.

Fleishman E, Fay JP, Murphy DD (2000) Upsides and downsides: Contrasting topographic gradients in species richness and associated scenarios for climate change. Journal of Biogeography, 27, 1209-1219.

Francis AP, Currie DJ (1998) Global patterns of tree species richness in moist forests: Another look. Oikos, 81, 598-602.

Fritz SA, Rahbek C (2012) Global patterns of amphibian phylogenetic diversity. Journal of Biogeography, 39, 1373-1382.

Gebrehiwot K, Demissew S, Woldu Z, Fekadu M, Desalegn T, Teferi E (2019) Elevational changes in vascular plants richness, diversity, and distribution pattern in Abune Yosef Mountain range, Northern Ethiopia. Plant Diversity, 41, 220-228.

Hettenbergerová E, Hájek M, Zelený D, Jiroušková J, Mikulášková E (2013) Changes in species richness and species composition of vascular plants and bryophytes along a moisture gradient. Preslia, 85, 369-388.

Hof C, Levinsky I, Araújo MB, Rahbek C (2011) Rethinking species ability to cope with rapid climate change. Global Change Biology, 17, 2987-2990.

Huang J, Yang LQ, Yu Y, Liu YM, Xie DF, Li J, He XJ, Zhou SD (2018) Molecular phylogenetics and historical biogeography of the tribe Lilieae (Liliaceae): Bi-directional dispersal between biodiversity hotspots in Eurasia. Annals of Botany, 122, 1245-1262.

Huang YJ, Jacques FMB, Su T, Ferguson DK, Tang H, Chen WY, Zhou ZK (2015) Distribution of Cenozoic plant relicts in China explained by drought in dry season. Scientific Reports, 5, 14212.

Hurlbert AH, Jetz W (2007) Species richness, hotspots, and the scale dependence of range maps in ecology and conservation. Proceedings of the National Academy of Sciences, USA, 104, 13384-13389.

Jacquemyn H, Butaye J, Hermy M (2001) Forest plant species richness in small, fragmented mixed deciduous forest patches: The role of area, time and dispersal limitation. Journal of Biogeography, 28, 801-812.

Jetz W, Thomas GH, Joy JB, Hartmann K, Mooers AO (2012) The global diversity of birds in space and time. Nature, 491, 444-448.

Jones HP, Barber NA, Gibson DJ (2019) Is phylogenetic and functional trait diversity a driver or a consequence of grassland community assembly? Journal of Ecology, 107, 2027-2032.

Kareiva P, Marvier M (2003) Conserving biodiversity coldspots: Recent calls to direct conservation funding to the world biodiversity hotspots may be bad investment advice. American Scientist, 91, 344-351.

Kerr JT (2001) Butterfly species richness patterns in Canada: Energy, heterogeneity, and the potential consequences of climate change. Ecology and Society, 5, art10.

Kinlock NL, Prowant L, Herstoff EM, Foley CM, Akin-Fajiye M, Bender N, Umarani M, Ryu HY, Şen B, Gurevitch J (2018) Explaining global variation in the latitudinal diversity gradient: Meta-analysis confirms known patterns and uncovers new ones. Global Ecology and Biogeography, 27, 125-141.

Kong HH, Zhang Y, Hong Y, Barker MS (2017) Multilocus phylogenetic reconstruction informing polyploid relationships of Aconitum subgenus Lycoctonum (Ranunculaceae) in China. Plant Systematics and Evolution, 303, 727-744.

Li FR, Peng SL, Chen BM, Hou YP (2010) A meta-analysis of the responses of woody and herbaceous plants to elevated ultraviolet-B radiation. Acta Oecologica, 36, 1-9.

Li M, He J, Zhao Z, Lyu R, Yao M, Cheng J, Xie L (2020) Predictive modelling of the distribution of Clematis sect. Fruticella s. str. under climate change reveals a range expansion during the Last Glacial Maximum. PeerJ, 8, 8729.

Li MY, Zhang SR, Xu QH, Xiao JL, Wen RL (2019) Spatial patterns of vegetation and climate in the North China Plain 
during the Last Glacial Maximum and Holocene climatic optimum. Science China Earth Sciences, 62, 1279-1287.

Liu QF, Liu Y, Sun XL, Zhang XF, Kang SRL, Ding Y, Zhang Q, Niu JM (2015) The explanation of climatic hypotheses to community species diversity patterns in Inner Mongolia grasslands. Biodiversity Science, 23, 463470. (in Chinese with English abstract) [刘庆福, 刘洋, 孙小丽, 张雪峰, 康 萨如拉, 丁勇, 张庆, 牛建明 (2015) 气候假说对内蒙古 草原群落物种多样性格局的解释. 生物多样性, 23, 463-470. ]

Liu YP, Su XY, Shrestha N, Xu XT, Wang SY, Li YQ, Wang QG, Sandanov D, Wang ZH (2019) Effects of contemporary environment and Quaternary climate change on drylands plant diversity differ between growth forms. Ecography, 42, 334-345.

Loarie SR, Duffy PB, Hamilton H, Asner GP, Field CB, Ackerly DD (2009) The velocity of climate change. Nature, 462, 1052-1055.

López-Pujol J, Zhang FM, Sun HQ, Ying TS, Ge S (2011a) Centres of plant endemism in China: Places for survival or for speciation? Journal of Biogeography, 38, 1267-1280.

López-Pujol J, Zhang FM, Sun HQ, Ying TS, Ge S (2011b) Mountains of Southern China as "plant museums" and "plant cradles": Evolutionary and conservation insights. Mountain Research and Development, 31, 261-269.

Lu LM, Mao LF, Yang T, Ye JF, Liu B, Li HL, Sun M, Miller JT, Mathews S, Hu HH, Niu YT, Peng DX, Chen YH, Smith SA, Chen M, Xiang KL, Le CT, Dang VC, Lu AM, Soltis PS, Soltis DE, Li JH, Chen ZD (2018) Evolutionary history of the angiosperm flora of China. Nature, 554, 234-238.

Mac Nally R (2000) Regression and model-building in conservation biology, biogeography and ecology: The distinction between and reconciliation of 'predictive' and 'explanatory' models. Biodiversity and Conservation, 9, 655-671.

Manafzadeh S, Staedler YM, Conti E (2017) Visions of the past and dreams of the future in the Orient: The Irano-Turanian region from classical botany to evolutionary studies. Biological Reviews, 92, 1365-1388.

Manish K, Pandit MK, Telwala Y, Nautiyal DC, Koh LP, Tiwari S (2017) Elevational plant species richness patterns and their drivers across non-endemics, endemics and growth forms in the Eastern Himalaya. Journal of Plant Research, 130, 829-844.

Martínez ML (2003) Facilitation of seedling establishment by an endemic shrub in tropical coastal sand dunes. Plant Ecology, 168, 333-345.

Massad TJ (2013) Ontogenetic differences of herbivory on woody and herbaceous plants: A meta-analysis demonstrating unique effects of herbivory on the young and the old, the slow and the fast. Oecologia, 172, 1-10.

Miller JT, Jolley-Rogers G, Mishler BD, Thornhill AH (2018) Phylogenetic diversity is a better measure of biodiversity than taxon counting. Journal of Systematics and Evolution, 56, 663-667.

Mishler BD, Guralnick R, Soltis PS, Smith SA, Soltis DE, Barve N, Allen JM, Laffan SW (2020) Spatial phylogenetics of the North American flora. Journal of Systematics and Evolution, 58, 393-405.

Morales CG, Pino MT, del Pozo A (2013) Phenological and physiological responses to drought stress and subsequent rehydration cycles in two raspberry cultivars. Scientia Horticulturae, 162, 234-241.

Muellner-Riehl AN, Schnitzler J, Kissling WD, Mosbrugger V, Rijsdijk KF, Seijmonsbergen AC, Versteegh H, Favre A (2019) Origins of global mountain plant biodiversity: Testing the 'mountain-geobiodiversity hypothesis'. Journal of Biogeography, 46, 2826-2838.

O’Brien EM (1993) Climatic gradients in woody plant species richness: Towards an explanation based on an analysis of southern Africa's woody flora. Journal of Biogeography, 20, 181-198.

Pretzsch H (2002) A unified law of spatial allometry for woody and herbaceous plants. Plant Biology, 4, 159-166.

Qi W, Bu HY, Liu K, Li WJ, Knops JMH, Wang JH, Li WL, Du GZ (2014) Biological traits are correlated with elevational distribution range of eastern Tibetan herbaceous species. Plant Ecology, 215, 1187-1198.

Qian H (2002) A comparison of the taxonomic richness of temperate plants in East Asia and North America. American Journal of Botany, 89, 1818-1825.

Qian H, Jin Y, Ricklefs RE (2017) Phylogenetic diversity anomaly in angiosperms between eastern Asia and eastern North America. Proceedings of the National Academy of Sciences, USA, 114, 11452-11457.

Qian H, Ricklefs RE (2000) Large-scale processes and the Asian bias in species diversity of temperate plants. Nature, 407, 180-182.

Qiu HJ, Sun JJ, Xu D, Jiao JJ, Xue M, Yuan WG, Shen AH, Jiang B, Li S (2020) The distribution dynamics of Ormosia mangrove under different climate change scenarios since the Last Glacial Maximum. Acta Ecologica Sinica, 40, 3016-3026. (in Chinese with English abstract) [邱浩杰, 孙 杰杰, 徐达, 焦洁洁, 薛敏, 袁位高, 沈爱华, 江波, 李胜 (2020) 末次盛冰期以来红豆树在不同气候变化情景下的 分布动态. 生态学报, 40, 3016-3026.]

Rabosky DL (2020) Speciation rate and the diversity of fishes in freshwaters and the oceans. Journal of Biogeography, 47, 1207-1217.

Rodrigues ASL, Gaston KJ (2002) Maximising phylogenetic diversity in the selection of networks of conservation areas. Biological Conservation, 105, 103-111.

Roscher C, Beßler H, Oelmann Y, Engels C, Wilcke W, Schulze ED (2009) Resources, recruitment limitation and invader species identity determine pattern of spontaneous invasion in experimental grasslands. Journal of Ecology, 97, 
32-47.

Sakai A, Malla SB (1981) Winter hardiness of tree species at high altitudes in the east Himalaya, Nepal. Ecology, 62, 1288-1298.

Salinas MJ, Casas JJ (2007) Riparian vegetation of two semi-arid Mediterranean rivers: Basin-scale responses of woody and herbaceous plants to environmental gradents. Wetlands, 27, 831-845.

Sandel B, Arge L, Dalsgaard B, Davies RG, Gaston KJ, Sutherland WJ, Svenning JC (2011) The influence of late quaternary climate-change velocity on species endemism. Science, 334, 660-664.

Saul-Tcherkas V, Steinberger Y (2011) Soil microbial diversity in the vicinity of a Negev desert shrub-Reaumuria negevensis. Microbial Ecology, 61, 64-81.

Schipper J, Chanson JS, Chiozza F, Cox NA, Hoffmann M, Katariya V, Lamoreux J, Rodrigues ASL, Stuart SN, Temple HJ, Baillie J, Boitani L, and other 117 authors (2008) The status of the world's land and marine mammals: Diversity, threat, and knowledge. Science. 322, 225-230.

Skov F, Svenning JC (2004) Potential Impact of Climatic Change on the Distribution of Forest Herbs in Europe. Echography, 27, 366-380.

Slezák M, Axmanová I (2016) Patterns of plant species richness and composition in deciduous oak forests in relation to environmental drivers. Community Ecology, 17, 61-70.

Smith SA, Beaulieu JM (2009) Life history influences rates of climatic niche evolution in flowering plants. Proceedings of the Royal Society B: Biological Sciences, 276, 4345-4352.

Smith SA, Donoghue MJ (2008) Rates of molecular evolution are linked to life history in flowering plants. Science, 322, 86-89.

Song B, Sun L, Lev-Yadun S, Moles AT, Zhang S, Jiang XL, Gao YQ, Xu Q, Sun H (2019) Plants are more likely to be spiny at mid-elevations in the Qinghai-Tibetan Plateau, south-western China. Journal of Biogeography, 47, 250-260.

Song YY, Zhou CB, Zhang WH (2011) Vegetation coverage, species richness, and dune stability in the southern part of Gurbantüngguet Desert. Ecological Research, 26, 79-86.

Sramkó G, Laczkó L, Volkova PA, Bateman RM, Mlinarec J (2019) Evolutionary history of the Pasque-flowers (Pulsatilla, Ranunculaceae): Molecular phylogenetics, systematics and rDNA evolution. Molecular Phylogenetics and Evolution, 135, 45-61.

Stein A, Kreft H (2015) Terminology and quantification of environmental heterogeneity in species-richness research. Biological Reviews, 90, 815-836.

Steinberg SL, van Bavel CHM, McFarland MJ (1990) Improved sap flow gauge for woody and herbaceous plants. Agronomy Journal, 82, 851-854.

Stuart-Smith RD, Bates AE, Lefcheck JS, Duffy JE, Baker SC,
Thomson RJ, Stuart-Smith JF, Hill NA, Kininmonth SJ, Airoldi L, Becerro MA, Campbell SJ, Dawson TP, Navarrete SA, Soler GA, Strain EMA, Willis TJ, Edgar GJ (2013) Integrating abundance and functional traits reveals new global hotspots of fish diversity. Nature, 501, 539-542.

Svenning JC, Skov F (2007) Ice age legacies in the geographical distribution of tree species richness in Europe. Global Ecology and Biogeography, 16, 234-245.

Tang CQ, Matsui T, Ohashi H, Dong YF, Momohara A, Herrando-Moraira S, Qian SH, Yang YC, Ohsawa M, Luu HT, Grote PJ, Krestov PV, LePage B, Werger M, Robertson K, Hobohm C, Wang CY, Peng MC, Chen X, Wang HC, Su WH, Zhou R, Li SF, He LY, Yan K, Zhu MY, Hu J, Yang RH, Li WJ, Tomita M, Wu ZL, Yan HZ, Zhang GF, He H, Yi SR, Gong HD, Song K, Song D, Li XS, Zhang ZY, Han PB, Shen LQ, Huang DS, Luo K, López-Pujol J (2018) Identifying long-term stable refugia for relict plant species in East Asia. Nature Communications, 9, 4488.

Tamura M (1995) Angiospermae : Ordnung Ranunculales Fam. Ranunculaceae, Die Natü rlichen . Pflanzenfamilien, 17, 89-105.

Tsirogiannis C, Sandel B (2016) PhyloMeasures: A package for computing phylogenetic biodiversity measures and their statistical moments. Ecography, 39, 709-714.

Tucker CM, Cadotte MW (2013) Unifying measures of biodiversity: Understanding when richness and phylogenetic diversity should be congruent. Diversity and Distributions, 19, 845-854.

Villéger S, Maire E, Leprieur F, Vila M (2017) On the risks of using dendrograms to measure functional diversity and multidimensional spaces to measure phylogenetic diversity: A comment on Sobral et al. (2016). Ecology Letters, 20, 554-557.

Wang QG, Su XY, Shrestha N, Liu YP, Wang SY, Xu XT, Wang ZH (2017) Historical factors shaped species diversity and composition of Salix in eastern Asia. Scientific Reports, 7, 42038.

Wang SY, Xu XT, Shrestha N, Zimmermann NE, Tang ZY, Wang ZH (2017) Response of spatial vegetation distribution in China to climate changes since the Last Glacial Maximum (LGM). PLoS ONE, 12, e0175742.

Wang W, Lin L, Xiang XG, Ortiz R del C, Liu Y, Xiang KL, Yu SX, Xing YW, Chen ZD (2016) The rise of angiosperm-dominated herbaceous floras: Insights from Ranunculaceae. Scientific Reports, 6, 27259.

Wang ZH, Fang JY, Tang ZY, Lin X (2011) Patterns, determinants and models of woody plant diversity in China. Proceedings of the Royal Society B: Biological Sciences, 278, 2122-2132.

Wang ZH, Fang JY, Tang ZY, Lin X (2012) Relative role of contemporary environment versus history in shaping diversity patterns of China's woody plants. Ecography, 35, 1124-1133. 
Wang ZH, Tang ZY, Fang JY (2009) The species-energy hypothesis as a mechanism for species richness patterns. Biodiversity Science, 17, 613-624. (in Chinese with English abstract) [王志恒, 唐志尧, 方精云 (2009) 物种多样性地 理格局的能量假说. 生物多样性, 17, 613-624.]

Watanabe S, Hajima T, Sudo K, Nagashima T, Takemura T, Okajima H, Nozawa T, Kawase H, Abe M, Yokohata T, Ise T, Sato H, Kato E, Takata K, Emori S, Kawamiya M (2011) MIROC-ESM 2010: Model description and basic results of $\mathrm{CMIP}_{5}$-20c3m experiments. Geoscientific Model Development, 4, 845-872.

Weiser MD, Enquist BJ, Boyle B, Killeen TJ, Jørgensen PM, Fonseca G, Jennings MD, Kerkhoff AJ, Lacher TE, Monteagudo A, Vargas MPN, Phillips OL, Swenson NG (2007) Latitudinal patterns of range size and species richness of New World woody plants. Global Ecology and Biogeography, 16, 679-688.

Xing YW, Ree RH (2017) Uplift-driven diversification in the Hengduan Mountains, a temperate biodiversity hotspot. Proceedings of the National Academy of Sciences, USA, 114, E3444-E3451.

Xu J, Jiang XL, Deng M, Westwood M, Song YG, Zheng SS (2016) Conservation genetics of rare trees restricted to subtropical montane cloud forests in southern China: A case study from Quercus arbutifolia (Fagaceae). Tree Genetics and Genomes, 12, 90.

Zhang ZJ, He JS, Li JS, Tang ZY (2015) Distribution and conservation of threatened plants in China. Biological Conservation, 192, 454-460.

Zhang ZS, Ramstein G, Schuster M, Li C, Contoux C, Yan Q (2014) Aridification of the Sahara Desert caused by Tethys Sea shrinkage during the Late Miocene. Nature, 513, 401-404.

Zhou NF, Zhang JP, Liu H, Zha WW, Pei D (2018) New protocols for paraffin sections of heterogeneous tissues of woody plants. Chinese Bulletin of Botany, 53, 653660. (in Chinese with English abstract) [周乃富, 张俊佩, 刘昊, 查 巍巍, 裴东 (2018) 木本植物非均质化组织石蜡切片制 作方法. 植物学报, 53, 653-660. ]

Zhu GL, Li J, Wei XH, He NP (2017) Longitudinal patterns of productivity and plant diversity in Tibetan alpine grasslands. Journal of Natural Resources, 32, 210-222. (in Chinese with English abstract) [朱桂丽, 李杰, 魏学红, 何念鹏 (2017) 青藏高寒草地植被生产力与生物多样性的经度格局. 自 然资源学报, 32, 210-222.]

Zhu H (2017) A biogeographical study on tropical flora of Southern China. Ecology and Evolution, 7, 10398-10408.

Zhu H, Cao M, Hu HB (2006) Geological history, flora, and vegetation of Xishuangbanna, southern Yunnan, China. Biotropica, 38, 310-317.

Zhu ZX, Nizamani MM, Sahu SK, Kunasingam A, Wang HF (2019) Tree abundance, richness, and phylogenetic diversity along an elevation gradient in the tropical forest of Diaoluo Mountain in Hainan, China. Acta Oecologica, 101, 103481.

Ziman SN, Keener CS (1989) A geographical analysis of the family Ranunculaceae. Annals of the Missouri Botanical Garden, 76, 1012-1049.

Zou DT, Wang QG, Luo A, Wang ZH (2019) Species richness patterns and resource plant conservation assessments of Rosaceae in China. Chinese Journal of Plant Ecology, 43, 1-15. (in Chinese with English abstract) [邹东廷, 王庆刚, 罗奥, 王志恒 (2019) 中国蓄薇科植物多样性格局及其 资源植物保护现状. 植物生态学报, 43, 1-15.]

Zu KL, Luo A, Shrestha N, Liu B, Wang ZH, Zhu XY (2019) Altitudinal biodiversity patterns of seed plants along Gongga Mountain in the southeastern Qinghai-Tibetan Plateau. Ecology and Evolution, 9, 9586-9596.

(责任编委：星耀武 责任编辑：黄祥忠)

\section{附录 Supplementary Material}

\section{附录1 物种分布记录数据来源}

Appendix 1 Data sources of species distribution records http://www.biodiversity-science.net/fileup/PDF/2020246-1.pdf 
李亦超, 陈永生, Denis Sandanov, 罗奥, 吕童, 苏香燕, 刘云鹏, 王庆刚, Viktor Chepinoga, Sergey Dudov, 王 伟，王志恒 (2021) 欧亚大陆东部毛茛科植物多样性格局及主导因子. 生物多样性, 29, 561-574.

http://www.biodiversity-science.net/CN/10.17520/biods.2020246

\section{附录1 物种分布记录数据来源}

Appendix 1 Data sources of species distribution records

4 An DG (2002) Higher Flora of Xiaolong Mountain in Gansu. Gansu National Press, Lanzhou. (in Chinese) [安定国 (2002) 甘肃省小陇山高等植物志. 甘肃民族出版社, 兰州.]

6 Bai SL, Wu DC (1994) Flora of Greater Khingan Mountains. Heilongjiang Science and Technology Press, Harbin. (in Chinese) [柏松林, 吴德成 (1994) 中国大兴安岭植物志. 黑龙江省科学技术出版社, 哈尔滨.]

8 Belaya S (1995) Morozov. Jewish AO, Russia.

Changbai Mountain Forest Ecosystem Positioning Station, Chinese Academy of Sciences (1982) The Plant List of Changbai Mountain. Changbai Mountain Forest Ecosystem Positioning Station, Yanji. (in Chinese) [中国科学院 长白山森林生态系统定位站 (1982) 长白山植物名录. 中国科学院长白山森林生态系统定位站, 延吉.]

Charkevicz PB (1985) Vascular Plants of the Soviet Far East. Vladivostok Dalnauka, Russia.

Chen HB, Zheng YJ, Li FZ (1997) Flora of Shandong (vol. 1-2). Qingdao Publishing House, Qingdao. (in Chinese)

14 [陈汉斌, 郑亦津, 李法曾 (1997) 山东植物志(上、下卷). 青岛出版社, 青岛.]

Chen SL (1962) Gramineae Flora of East China. Jiangsu People’s Publishing House, Nanjing. (in Chinese) [陈守良 (1962) 华东禾本科植物志. 江苏人民出版社, 南京.]

Chen XQ (2002) Higher Plants of China (vol. 13). Qingdao Publishing House, Qingdao. (in Chinese) [陈心启 (2002) 中国高等植物第十三卷. 青岛出版社, 青岛.]

Chen XX, Zhou Z, Hu RY, Ding BY (2013) Three new records of vascular plants in Zhejiang Province. Journal of Wenzhou University (Natural Sciences), 34, 54-56. (in Chinese with English abstract) [陈贤兴, 周庄, 胡仁勇, 丁炳扬 (2013) 浙江维管植物新纪录. 温州大学学报(自然科学版), 34, 54-56.]

Chen YO (2015) The Study of Higher Plant Diversity in Dalian Chengshantou Coastal Landform National Nature Reserve. Master dissertation, Liaoning Normal University, Dalian. (in Chinese with English abstract) [陈雨鸥 (2015) 大连城山头海滨地貌国家级自然保护区高等植物多样性研究. 硕士学位论文, 辽宁师范大学, 大连.]

Cheng CH (2016) Rare and endangered plants in Wudaoxia Nature Reserve and countermeasures for protection. Hubei Forestry Science and Technology, 45(4), 69-72. (in Chinese) [程传宏 (2016) 五道峡自然保护区珍稀濒危植物 及其保护对策. 湖北林业科技, 45(4), 69-72.]

28 Cheng JQ, Yang ZJ, Liu P (1992) Timber Flora of China. China Forestry Publishing House, Beijing. (in Chinese) [成 俊卿, 杨宗驹, 刘鹏 (1992) 中国木材志. 中国林业出版社, 北京.]

China Arboreal Editorial Committee (1983) Tree Flora of China. China Forestry Publishing House, Beijing. (in Chinese) [中国树木志编辑委员会 (1983) 中国树木志. 中国林业出版社, 北京.]

Institute of Agricultural Biology, Sichuan Branch, Chinese Academy of Sciences (1962-1963) Wild Economic Flora of Sichuan. Sichuan People's Publishing House, Chengdu. (in Chinese) [中国科学院四川分院农业生物研究所 (1962-1963) 四川野生经济植物志. 四川人民出版社, 成都.]

Guangxi Institute of Botany, Chinese Academy of Sciences (1991) Flora of Guangxi (vol.1-6). Guangxi Science and Technology Press, Nanning. (in Chinese) [中国科学院广西植物研究所 (1991)广西植物志(1-6 卷). 广西科学 技术出版社, 南宁.]

38 Cui YW (1953) Essentials of North China Economic Plants. Science Press, Beijing. (in Chinese) [崔友文 (1953) 华 北经济植物志要. 科学出版社, 北京.]

Department of Health of Zhejiang Province (1960) Medicinal Flora of Tianmu Mountains. Zhengjiang People’s Publishing House, Hangzhou. (in Chinese) [浙江省卫生厅 (1960) 浙江天目山药用植物志. 浙江人民出版社, 杭州.]

Department of Pharmacy Shanghai First Hospital (1961) Medicinal Flora of Hangzhou. Shanghai Science and

44 Technology Publisher, Shanghai. (in Chinese) [上海第一医院药学系生药学教研组 (1961) 杭州药用植物志. 上海科学技术出版社, 上海.]

Du YB (2000) Wile Resource Flora of Hebei. Hebei University, Baoding. (in Chinese) [杜怡斌 (2000) 河北野生资 源植物志. 河北大学出版社, 保定.]

Editorial Committee of Flora of the USSR. (1963-1977) Flora of the USSR: vol. I-XXI; vol. XXIV. Keter Publishing House Jerusalem Ltd., Jerusalem, Israel. (in English, translated from the Russian)

Editorial Committee of Flora of the USSR. (1999-2004) Flora of the USSR: Alphabetical Indexes to vol. I-XXX; vol. XXII-XXIII; vol. XXV-XXIX. Smithsonian Institution Libraries Washington, DC, USA. (in English, translated from the Russian) 
李亦超, 陈永生, Denis Sandanov, 罗奥, 吕童, 苏香燕, 刘云鹏, 王庆刚, Viktor Chepinoga, Sergey Dudov, 王 伟，王志恒 (2021) 欧亚大陆东部毛茛科植物多样性格局及主导因子. 生物多样性, 29, 561-574.

http://www.biodiversity-science.net/CN/10.17520/biods.2020246

Editorial Committee of Flora of Gansu (2005) Flora of Gansu. Gansu Science \& Technology Press, Yinchuan. (in Chinese) [甘肃植物志编辑委员会 (2005) 甘肃植物志. 甘肃科学技术出版社, 兰州.]

Fang JY, Wang ZH, Tang ZY (2011) Atlas of Woody Plants in China: Distribution and Climate. Higher Education Press, Beijing \& Springer, Berlin. (in Chinese) [方精云, 王志恒, 唐志尧 (2011) 中国木本植物图集: 分布与 气候. 高等教育出版社, 北京 \& Springer, Berlin.]

Flora of Anhui Collaborating Group (1986) Flora of Anhui (vol. 1-5). Anhui Science and Technology Publishing House, Hefei. (in Chinese) [安徽植物志协作组 (1986) 安徽植物志(1-5 卷). 安徽科学技术出版社, 合肥.]

Flora of China (efloras) (1990) http://www. efloras. org/browse. aspx?flora_id=2. (accessed on 2019-05-01)

Flora of Fujian Editorial Committee (1994) Flora of Fujian. Forestry Survey and Design, Fuzhou. (in Chinese) [福建 植物志编辑委员会 (1994) 福建植物志. 林业勘察设计, 福州.]

Flora of Guizhou Editorial Committee (2000) Flora of Guizhou (vol.1-10). Guizhou Science and Technology Press, Guiyang. (in Chinese) [贵州植物志编辑委员会 (2000) 贵州植物志(1-10 卷). 贵州科技出版社, 贵阳.]

Flora of Hebei Editorial Committee (1986) Flora of Hebei (vol.1-3). Hebei Science and Technology Press, Shijiazhuang. (in Chinese) [河北植物志编辑委员会 (1986) 河北植物志(1-3 卷). 河北科学技术出版社, 石家 庄.]

Flora of Henan Editorial Committee (2000) Flora of Henan (vol.1-4). Henan Science and Technology Press, Zhengzhou. (in Chinese) [河南植物志编纂委员会 (2000) 河南植物志(1-4 卷). 河南科技出版社, 郑州.]

Flora of Hunan Editorial Committee (2000) Flora of Hunan (vol.1-3). Hunan Science and Technology Press, Changsha. (in Chinese) [湖南植物志编辑委员会 (2000) 湖南植物志(1-3 卷). 湖南科技出版社, 长沙.]

Flora of Inner Mongolia Editorial Committee (1985-1998) Flora of Inner Mongolia (vol.1-6). Inner Mongolia People's Publishing House, Huhehaote. (in Chinese) [内蒙古植物志编辑委员会 (1985-1998) 内蒙古植物志 (1-6 卷). 内蒙古人民出版社, 呼和浩特.]

Flora of Jiangxi Editorial Committee (2014) Flora of Jiangxi (vol.1-6). Jiangxi Science and Technology Press, Nanchang. (in Chinese) [江西植物志编辑委员会 (2014) 江西植物志(1-6 卷). 江西科学技术出版社, 南昌.]

Flora of Shanxi Editorial Committee (2004) Flora of Shanxi (vol.1-5). China Science and Technology Press, Beijing. (in Chinese) [山西植物志编辑委员会(2004) 山西植物志(1-5 卷). 中国科学技术出版社, 北京.]

Flora of Sichuan Editorial Committee (1981) Flora of Sichuan (vol.1-16; vol. 21). Sichuan People's Publishing House, Chengdu. (in Chinese) [四川植物志编辑委员会 (1981) 四川植物志(1-16 卷; 21 卷). 四川人民出版 社, 成都.]

Flora of Xinjiang Editorial Committee (1992-1996) Flora of Xinjiang (vol.1-6). Xinjiang Science Technology and Health Press, Wulumuqi. (in Chinese) [新疆植物志编辑委员会 (1992-1996) 新疆植物志(1-6 卷). 新疆科技 卫生出版社, 乌鲁木齐.]

Flora of Zhejiang Editorial Committee (1992-1993) Flora of Zhejiang (vol.2-7). Zhejiang Science and Technology Press, Hangzhou. (in Chinese) [浙江植物志编辑委员会 (1992-1993) 浙江植物志(2-7 卷). 浙江科学技术出 版社, 杭州.]

Fu GA, Hong XJ (2008) Flora of vascular plants of Jianfengling Hainan Island, Guihaia, 28, 226-229. (in Chinese with English abstract) [符国瑗，洪小江 (2008) 海南岛尖峰岭的维管植物区系, 广西植物, 28, 226-229.]

Fu LG (2000) Higher Plants of China (vol.3). Qingdao Publishing House, Qingdao. (in Chinese) [傅立国 (2000) 中 国高等植物第三卷. 青岛出版社, 青岛.]

Fu LG (2001) Higher Plants of China (vol.8). Qingdao Publishing House, Qingdao. (in Chinese) [傅立国 (2001) 中 国高等植物第八卷. 青岛出版社, 青岛.]

94 Fu LG (2003) Higher Plants of China (vol.6). Qingdao Publishing House, Qingdao. (in Chinese) [傅立国 (2003) 中 国高等植物第六卷. 青岛出版社, 青岛.]

96 Fu LG (2004) Higher Plants of China (vol.10). Qingdao Publishing House, Qingdao. (in Chinese) [傅立国 (2004) 中国高等植物第十卷. 青岛出版社, 青岛.]

98 Fu LG, Hong T (2005) Higher Plants of China (vol.11). Qingdao Publishing House, Qingdao. (in Chinese) [傅立国, 洪涛 (2005) 中国高等植物第十一卷. 青岛出版社, 青岛.]

100 Fu PY (1998) Herbaceous Flora of Northeast China (vol.1-12). Science Press, Beijing. (in Chinese) [傅沛云 (1998) 东北草本植物志(1-12 卷). 科学出版社, 北京.]

102 Global Biodiversity Information Facility (GBIF) (2014) https://www.gbif.org. (accessed on 2019-04-17)

He SY (1993) Flora of Beijing. Beijing Publishing House, Beijing. (in Chinese) [贺士元 (1993) 北京植物志. 北京 出版社, 北京.] 
李亦超, 陈永生, Denis Sandanov, 罗奥, 吕童, 苏香燕, 刘云鹏, 王庆刚, Viktor Chepinoga, Sergey Dudov, 王 伟，王志恒 (2021) 欧亚大陆东部毛茛科植物多样性格局及主导因子. 生物多样性, 29, 561-574.

http://www.biodiversity-science.net/CN/10.17520/biods.2020246

Institute of Botany Chinese Academy of Sciences (1974) Flora of Qinling Mountains (vol.1). Science Press, Beijing. (in Chinese) [中国科学院植物研究所 (1974) 秦岭植物志(第一卷). 科学出版社, 北京.]

Jiangsu Institute of Botany (2017) Flora of Jiangsu (vol. 2-5). Jiangsu People’s Publishing House, Nanjing. (in Chinese) [江苏省植物研究所 (2017) 江苏植物志(2-5 卷). 江苏人民出版社, 南京.]

Institute of Forestry and Soil Chinese Academy of Sciences (1959) Medicinal Flora of Northeast China. Science Press, Beijing. (in Chinese) [中国科学院林业土壤研究所 (1959) 东北药用植物志. 科学出版社, 北京.]

Institute of Forestry and Soil Chinese Academy of Sciences (1959) Illustrated Woody Flora of Northeast China.

112 Science Press, Beijing. (in Chinese) [中国科学院林业土壤研究所 (1955) 东北木本植物图志. 科学出版社, 北京.]

114 Institute of Forestry and Soil Chinese Academy of Sciences (1960) Economic Flora of Liaoning. Liaoning People’s Publishing House, Shenyang. (in Chinese) [中国科学院林业土壤研究所 (1960) 辽宁经济植物志. 辽宁人民出 版社, 沈阳.]

Ivanova O (1983) Flora of northern part of Lake Baikal. HoBoch6Иpck, Russia. (in Russian)

118 Jiangsu Provincial Department of Commerce and Institute of Botany Jiangsu Province and Chinese Academy of Sciences (1959) Wild Flora of Jiangsu. Jiangsu People’s Publishing House, Nanjing. (in Chinese) [江苏省商业厅, 中国科学院植物研究所南京中山植物园编 (1959) 江苏野生植物志. 江苏人民出版社, 南京.]

Koropachinskiĭ O (2002) Woody Plants of the Asian Part of Russia. Nauka, Russia. (in Russian)

Koropachinsky IY (2015) North Asian Woody Plants. vol. 1: Taxaceae - Rosaceae.; vol. 2: Fabaceae - Asteraceae. Geo Publishing House, Novosibirsk. (in Russian)

124 Krasnoborov A (2012) Artemov. Altai Republic, Russia. (in Russian)

Krasnoborow O (1988) Flora of Siberia. СИGМРСКОЕ ОТзЕдеММЕ, Russia. (in Russian)

Kunming Institute of Botany Chinese Academy of Sciences (1983) Flora of Xizang (vol.1-5). Science Press, Beijing. (in Chinese) [中国科学院昆明植物研究所 (1983) 西藏植物志(1-5 卷). 科学出版社, 北京.]

Kunming Institute of Botany Chinese Academy of Sciences (1997-2006) Flora of Yunnan (vol.1-16). Science Press, Beijing. (in Chinese) [中国科学院昆明植物研究所 (1997-2006) 云南植物志(1-16 卷). 科学出版社, 北京.]

Lanzhou Institute of Desert Research Chinese Academy of Sciences (1992) Flora of Desert Area in China. Science Press, Beijing. (in Chinese) [中国科学院兰州沙漠研究所 (1992) 中国沙漠植物志. 科学出版社, 北京.]

Li FZ, Li WQ, Fan SJ (2016) Woody Flora of Shandong (vol.1-2). Science Press, Beijing. (in Chinese) [李法曾, 李 文清, 㚞守金 (2016) 山东木本植物志(上下卷). 科学出版社, 北京.]

Li RM, ShangGuan TL, Zhang JL, Hao J (2015) Hengshan Resources Plant History (vol.1-2). Shanxi Science and Technology Press, Taiyuan. (in Chinese) [李日明,上官铁梁, 张吉林, 郝婧 (2015) 恒山资源植物志要(上、下 卷). 山西科技出版社, 太原.]

Li SX (1988-1992) Flora of Liaoning (vol.1-2). Liaoning Science and Technology Press, Shenyang. (in Chinese) [李 书心 (1988-1992) 辽宁植物志(上、下卷). 辽宁科学技术出版社, 沈阳.]

Li YJ (1987) Woody Flora of Qinghai. Qinhai People’s Publishing House, Xining. (in Chinese) [李耀阶 (1987) 青 海木本植物志. 青海人民出版社, 西宁.]

Liang GL, Yi SR (2013) Resources of Wild Medicinal Plants in Jinfoshan Mountains. China Science and Technology

Press, Bejing. (in Chinese) [梁国鲁,易思荣 (2013) 金佛山野生药用植物资源. 中国科学技术出版社, 北京.]
Liu TW, Zhang YF (1990) Flora of Taiyuan. China Science and Technology Press, Bejing. (in Chinese) [刘天慰, 张 云峰 (1990) 太原植物志. 中国科学技术出版社, 北京.]

Lu JL, Yu XY, Zhang JP (1998) Woody Plants Illustrated Book in Henan. New Century Press, Guangzhou. (in Chinese) [卢昫林, 余学友, 张俊朴 (1998) 河南木本植物图鉴. 新世纪出版社, 广州.]

Lu, Q, Wang JH and Chu JM (2012) Desert Plants in China. China Forestry Publishing House, Beijing. (in Chinese) [卢琦，王继和，褚建民 (2012) 中国荒漠植物图鉴. 中国林业出版社，北京.]

Ma DZ (2007) Flora of Ningxia (vol.1-2). Ningxia People’s Publishing House, Yinchuan. (in Chinese) [马德滋 (2007) 宁夏植物志(上、下卷). 宁夏人民出版社, 银川.]

Mao ZZ (1997) Investigation of Guangxi Plant List. Guihaia, 17, 187-192. (in Chinese) [毛宗铮 (1997) 广西植物 名录. 广西植物, 17, 187-192.]

Mei ZF (1999) Common Trees in Beijing. China Forestry Publishing House, Beijing. (in Chinese) [梅志奋 (1999)

154 北京常见树木. 中国林业出版社, 北京.]

National Specimen Information Infrastructure (NSII) (2013) A Biodiversity e-Science Infrastructure in China. http://www.nsii.org.cn/. (accessed on 2019-05-01) 
李亦超, 陈永生, Denis Sandanov, 罗奥, 吕童, 苏香燕, 刘云鹏, 王庆刚, Viktor Chepinoga, Sergey Dudov, 王 伟，王志恒 (2021) 欧亚大陆东部毛茛科植物多样性格局及主导因子. 生物多样性, 29, 561-574.

http://www.biodiversity-science.net/CN/10.17520/biods.2020246

Niu CS (1990) Tree Flora of Shaannxi. China Forestry Publishing House, Beijing. (in Chinese) [牛春山 (1990) 陕 西树木志. 中国林业出版社, 北京.]

Northwest Botanical Institute Chinese Academy of Sciences (2000) Flora of Loess Plateau. Science Press, Beijing. (in Chinese) [中国科学院西北植物研究所编著 (2000) 黄土高原植物志. 科学出版社, 北京.]

Northwest Institute of Plateau Biology Chinese Academy of Sciences (1996) Flora of Qinghai (vol.1-4). Qinghai People's Publishing House, Xining. (in Chinese) [中国科学院西北高原生物研究所 (1996) 青海植物志(1-4 卷). 青海人民出版社, 西宁.]

164 Олонова MB (2016) Genus Poa in Siberia. Издательство ТоМсКоrо унИверсИТеТа, Russia. (in Russian)

Qi CJ, Lin QZ (2000) Tree Flora of Hunan. Hunan Science and Technology Press, Changsha. (in Chinese) [祁承经, 林亲众 (2000) 湖南树木志. 湖南科学技术出版社, 长沙.]

Qinghai-Tibet Plateau Comprehensive Scientific Investigation Team of Chinese Academy of Sciences (1994) Vascular Plants in Hengduan Mountains. Science Press, Beijing. (in Chinese) [中国科学院青藏高原综合科学考 察队 (1994) 横断山区维管束植物. 科学出版社, 北京.]

170 Shanghai Academy of Science and Technology (1999) Flora of Shanghai (vol.1-2). Shanghai Science and Technological Literature Press, Shanghai. (in Chinese) [上海科学院 (1999) 上海植物志(上、下卷). 上海科学 技术文献出版社, 上海.]

Shanxi Academy of Forestry (2001) Woody Flora of Shanxi. China Forestry Publishing House, Beijing. (in Chinese) [山西省林业科学研究院 (2001) 山西树木志. 中国林业出版社, 北京.]

Shanxi Agricultural Division Commission (1990) Economic Flora of Shanxi. China Forestry Publishing House, Beijing. (in Chinese) [山西省农业区划委员会 (1990) 山西省经济植物志. 中国林业出版社, 北京.]

South China Botanical Garden, Chinese Academy of Sciences (1956) Flora of Guangzhou. Science Press, Beijing. (in Chinese) [中国科学院华南植物研究所 (1956) 广州植物志. 科学出版社, 北京.]

South China Botanical Garden, Chinese Academy of Sciences (1964-1977) Flora of Hainan (vol.1-4). Science Press, Beijing. (in Chinese) [中国科学院华南植物研究所 (1964-1977) 海南植物志(1-4 卷). 科学出版社, 北京.]

South China Botanical Garden Chinese Academy of Sciences (1987) Flora of Guangdong. Guangdong Science and Technology Press, Guangzhou. (in Chinese) [中国科学院华南植物研究所 (1987) 广东植物志. 广东科技出版 社, 广州.]

Undarmaa J, Okuro T, Manibazar N, Yamanaka N (2015) Rangeland Plants of Mongolia. Munkhiin Useg Co, Itd., Ulaanbaatar, Mongolia. (in Mongolian)

Urgamal M., Oyuntsetseg B (2017) Atlas of the Endemic Vascular Plants of Mongolia. Bembi San Press, Mongolia. (in Mongolian)

188 Urgamal M., Oyuntsetseg B, Nyambayar D and Dulamsuren C (2014) Conspectus of the vascular plants of Mongolia. Admon Printing Press, Ulaanbaatar, Mongolia. (in Mongolian)

190 Virtual Guide to the Flora of Mongolia (Flora GREIF) (2010) http://greif. unigreifswald. de/floragreif/. (accessed on 2017-05-01)

192 Wang WC (1995) Key List of Vascular Plants in Wuling Mountain Area. Science Press, Beijing. (in Chinese) [王文 采 (1995) 武陵山地区维管植物检索表. 科学出版社, 北京.]

194 Woody flora of Anhui editorial group (1983) Woody Flora of Anhui. Anhui Science and Technology Press, Hefei. (in Chinese) [安徽木本植物编写组 (1983) 安徽木本植物. 安徽科学技术出版社, 合肥.]

Wu YH (2008) The Vascular Plants and their Eco-geographical Distribution in the Qinghai-Tibet Plateau Area. Science Press, Beijing. (in Chinese) [吴玉虎 (2008) 青藏高原维管植物及其生态地理分布. 科学出版社, 北 京.]

Wu YH (2013) Flora of Kunlun. Qinghai Ethnic Publishing House, Xining. (in Chinese) [吴玉虎 (2013) 昆仑植物 志. 青海民族出版社, 西宁.]

Wuhan Botanical Garden, Chinese Academy of Sciences (2000) Flora of Hubei (vol.1-4). Hubei Science and Technology Press, Wuhan. (in Chinese) [中国科学院武汉植物研究所 (2000) 湖北植物志(1-4 卷). 湖北科技 出版社, 武汉.]

204 Xie H, Sun C (2014) Guizhou Maple Resource and Utilization Status. Science Press, Beijing. (in Chinese) [谢华, 孙 超 (2014) 贵州桑科植物资源图鉴及利用现状. 科学出版社, 北京.]

206 Yakubov C (2004) Chernyagina. Kamchatka, Russia. (in Russian)

Yi TP (1997) Bamboo Flora of Sichuan. China Forestry Publishing House, Beijing. (in Chinese) [易同培 (1997) 四 川竹类植物志. 中国林业出版社，北京.] 
李亦超, 陈永生, Denis Sandanov, 罗奥, 吕童, 苏香燕, 刘云鹏, 王庆刚, Viktor Chepinoga, Sergey Dudov, 王 伟，王志恒 (2021) 欧亚大陆东部毛茛科植物多样性格局及主导因子. 生物多样性, 29, 561-574.

http://www.biodiversity-science.net/CN/10.17520/biods.2020246

Yu SX, Xu WB, Wu JY, Yu LY, Huang YF (2017) List of Seed Plants in the Karst Area of Yunnan Guizhou and Guangxi. China Environment Press, Beijing. (in Chinese) [于胜祥, 许为斌, 武建勇, 余丽莹, 黄云峰 (2017) 滇黔桂喀斯特地区种子植物名录. 中国环境出版社, 北京.]

212 Zhang DX (2011) The Plant List of Nanling Mountains. Science Press, Beijing. (in Chinese) [张奠湘 (2011) 南岭 植物名录. 科学出版社, 北京.]

214 Zhao JC, Wang ZJ, Li L (2005) Higher Flora of Hebei. Science Press, Beijing. (in Chinese) [赵建成, 王振杰, 李琳 (2005) 河北高等植物名录. 科学出版社, 北京.]

216 Zhao YZ (2006) Vascular Plants of Plateau Ordos. Inner Mongolia People’s Publishing House, Hohhot. (in Chinese) [赵一之 (2006) 鄂尔多斯高原维管植物. 内蒙古人民出版社, 呼和浩特.]

218 Zhao YZ (2012) Classification and Its Florristic Ecological Geographic Distribution of Vascular Plant in Inner Mongolia. Inner Mongolia University, Hohhot. (in Chinese) [赵一之 (2012) 内蒙古维管束植物的分类及其区 系生态地理分布. 内蒙古大学出版社, 呼和浩特.]

Zhou YL (1955) Xiaoxinganling Mountain Woody Plants. China Forestry Publishing House, Beijing. (in Chinese) [周以良 (1955) 小兴安岭木本植物. 中国林业出版社, 北京.]

Zhou YL (1998) Flora of Heilongjiang (vol.4-11). Northeast Forestry University, Harbin. (in Chinese) [周以良 (1998) 黑龙江省植物志(4-11 卷). 东北林业大学出版社, 哈尔滨.]

Zhu ZY, Liang CZ, Li ZG (2011) Flora of Helan Mountain. Sunshine Press, Beijing. (in Chinese) [朱宗元, 梁存柱, 李志刚 (2011) 贺兰山植物志. 阳光出版社, 北京.]

Zi XZ, Zhang DC (2006) Flora of Dabieshan Mountains. China Forestry Publishing House, Beijing. (in Chinese) [訾 兴中, 张定成 (2006) 大别山植物志. 中国林业出版社, 北京.]

Издательство О (1974) Endemic alpine species of Northern Asia. Hobochbhpck, Russia. (in Russian) 